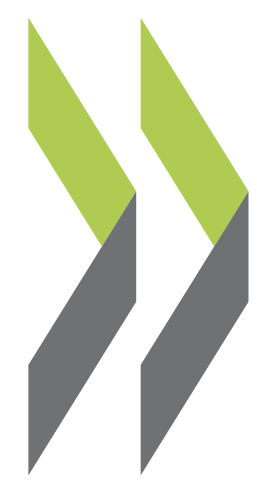

OECD Working Papers on International Investment 2015/03

Currency-based measures targeting banks - Balancing national regulation of risk and financial openness
Annamaria de Crescenzio,

Marta Golin,

Anne-Christelle Ott 


\section{OECD WORKING PAPERS ON INTERNATIONAL INVESTMENT}

The international investment working paper series - including policies and trends and the broader implications of multinational enterprise - is designed to make available to a wide readership selected studies by the OECD Investment Committee, OECD Investment Division staff, or by outside consultants working on OECD Investment Committee projects.

The papers are generally available only in their original language English or French with a summary in the other if available.

Comment on the series is welcome, and should be sent to investment@oecd.org or the Investment Division, OECD, 2, rue André Pascal, 75775 PARIS CEDEX 16, France.

OECD WORKING PAPERS ON INTERNATIONAL INVESTMENT are published on www.oecd.org/daf/inv/investment-policy/working-papers.htm.

OECD Working Papers should not be reported as representing the official views of the OECD or of its member countries. The opinions expressed and arguments employed are those of the authors.

Working Papers describe preliminary results or research in progress by the author(s) and are published to stimulate discussion on a broad range of issues on which the OECD works. Comments on Working Papers are welcomed, and may be sent to investment@oecd.org or the Investment Division, Directorate for Financial and Enterprise Affairs, OECD, 2 rue André-Pascal, 75775 Paris Cedex 16, France.

This document and any map included herein are without prejudice to the status of or sovereignty over any territory, to the delimitation of international frontiers and boundaries and to the name of any territory, city or area.

The statistical data for Israel are supplied by and under the responsibility of the relevant Israeli authorities. The use of such data by the OECD is without prejudice to the status of the Golan Heights, East Jerusalem and Israeli settlements in the West Bank under the terms of international law. rights@oecd.org or by fax 33145249930. 


\title{
Currency-based measures targeting banks - balancing national regulation of risk and financial openness
}

\author{
by \\ Annamaria de Crescenzio, Marta Golin, Anne-Christelle Ott ${ }^{1}$
}

\begin{abstract}
This paper presents and analyses new datasets of de jure Currency-Based Measures (CBMs) directed at banks in a sample of 49 countries between 2005 and 2013. These measures are bank regulations that apply a discrimination-e.g. a less favourable treatment-on the basis of the currency of an operation, typically foreign currencies. The new data shows that CBMs have been increasingly used in the post-crisis period, including for macro-prudential purposes. In particular, some Emerging Market Economies, including some OECD countries, have increasingly resorted to and tightened their CBMs, especially to manage capital inflows. Information from these new datasets is also matched with measures on countries' inability to borrow in domestic currency on international markets, defined as the original sin concept. With the exception of China, only countries suffering from original sin used and tightened CBMs on banks' foreign exchange liabilities.
\end{abstract}

Approved by Pierre Poret, Deputy Director, OECD Directorate for Financial and Enterprise Affairs

JEL Classification: C82, E58, F3, F38, F65, G28

Key words: foreign currency-related measures, currency-based measures, currency risk, macro-prudential policy, capital controls, capital flows, banking regulation, original sin, financial stability.

\footnotetext{
${ }^{1}$ The authors are part of the Investment Division of the OECD Directorate for Financial and Enterprise Affairs. We are grateful to Pierre Poret, Angel Palerm, Ana Novik, Kiril Kossev and Francesco Molteni for their helpful comments. We would also like to thank Mr. Denis Petre and Mr. Pablo Garcia-Luna at the BIS for providing us with the data necessary to compute the original sin indexes; Mr. Ricardo Haussman and Mr. Ugo Panizza for sharing their data on original sin indices.
} 



\section{TABLE OF CONTENTS}

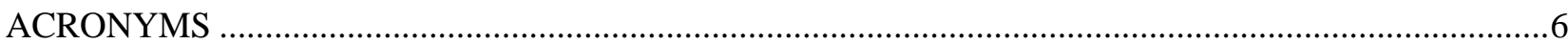

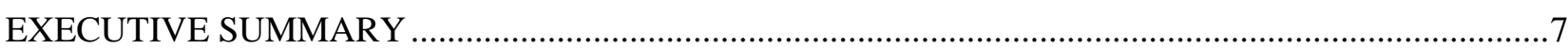

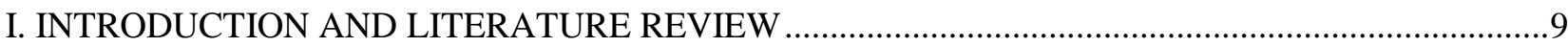

II. CONSTRUCTING THE DATASETS OF CURRENCY-BASED MEASURES .................................11

III. EVOLUTION IN THE USE OF CURRENCY-BASED MEASURES IN THE

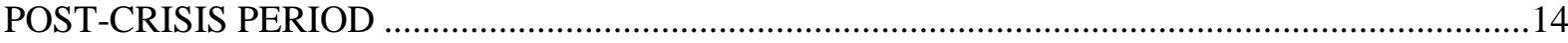

IV. THE USE OF CURRENCY-BASED MEASURES ON FX LIABILITIES

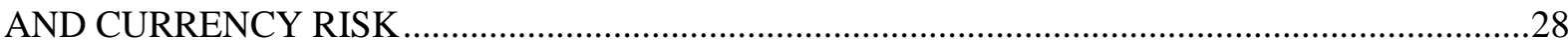

V. CONCLUSIONS AND POSSIBLE AREAS OF FUTURE WORK ….................................................32

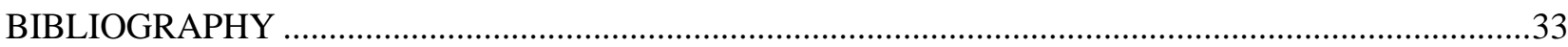

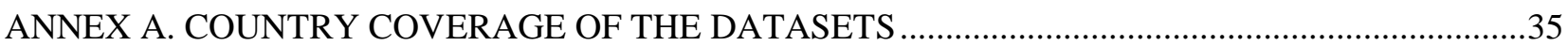

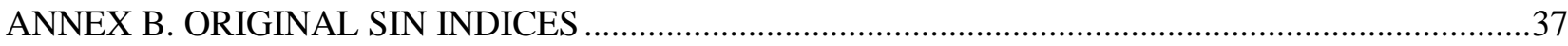

LIST OF OECD WORKING PAPERS ON INTERNATIONAL INVESTMENT ......................................38

\section{Tables}

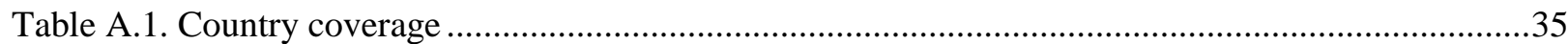

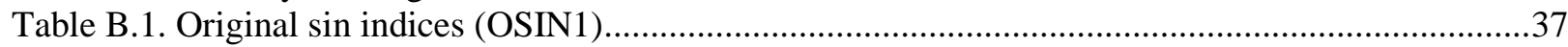

\section{Figures}

Figure 1. The new datasets provide highly disaggregated information covering 56 categories ...............13

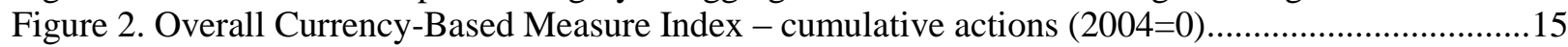

Figure 3. CBM Index for measures targeting FX liabilities of banks - cumulative actions (2004=0).......15

Figure 4. Breakdown of CBM Index on whether the measure manages inflows, outflows

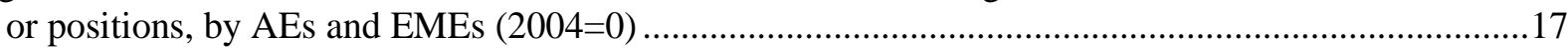

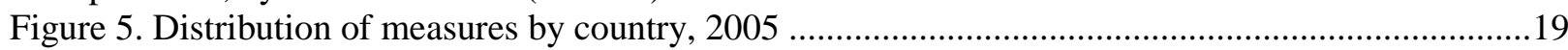

Figure 6. Breakdown of measures by type of capital flows managed and country groups, 2005 .............19

Figure 7. Breakdown by classes of measures and country groups, 2005 ..............................................20

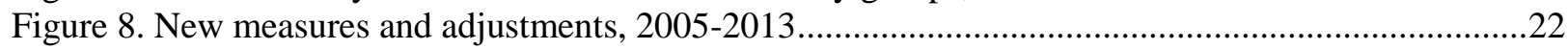

Figure 9. Breakdown of tightening changes by AEs and EMEs (\% of total), 2005-2013 ......................24

Figure 10. Breakdown of easing changes by AEs and EMEs (\% of total), 2005-2013 ..........................24

Figure 11. With the exception of China, only countries suffering from original sin used and tightened CBMs on banks' FX liabilities .30

\section{Boxes}

Box 1. The experiences of Malaysia, the Philippines and Thailand …................................................16

Box 2. The ESRB's recommendation on lending in foreign currencies ...............................................26

Box 3. Recording changes in differentiated reserve requirements .....................................................27

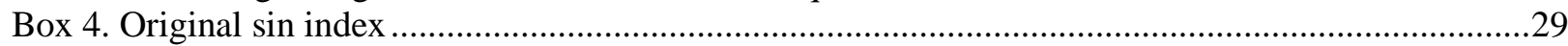




\section{ACRONYMS}

AREAER Annual Report on Exchange Arrangements and Exchange Restrictions

AEs $\quad$ Advanced Economies

BIS Bank of International Settlements

CBMs Currency-Based Measures

CFMs Capital Flow Management Measures

EMEs $\quad$ Emerging Market Economies

ESRB European Stability Risk Board

FX Foreign Exchange

IMF International Monetary Fund

MPMs Macro-Prudential Measures

MSCI Morgan Stanley Capital International

OECD Organisation for Economic Co-operation and Development

WEO World Economic Outlook 


\section{EXECUTIVE SUMMARY}

This paper presents and analyses new datasets of de jure Currency-Based Measures (CBMs) directed at banks in a sample of 49 countries, including 34 OECD and 15 non-OECD countriesbetween 2005 and 2013. These measures are bank regulations discriminating on the basis of the currency of an operation-in other words, measures that apply a less favourable treatment to operations by banks in a particular currency (typically foreign currencies). ${ }^{2}$ A complete definition of CBMs included in our datasets is provided in Section I.

The datasets draw on information either reported in the International Monetary Fund (IMF)'s Annual Report on Exchange Arrangements and Exchange Restrictions (AREAER) or provided by delegates to the Advisory Task Force on the OECD Codes of Liberalisation, in a survey conducted in 2014. A distinguishing and important feature of the datasets is the granularity of the information collected, which covers 56 categories.

While noting that the datasets do not capture the intensity or magnitude of measures-a standard challenge in the literature so far-some patterns emerge from the analysis of the use of CBMs:

1. In the pre-crisis period (2005) Emerging Market Economies (EMEs) had more CBMs in place than Advanced Economies (AEs). ${ }^{3}$ AEs mainly resorted to conventional measures on the net Foreign Exchange (FX) position of banks, while EMEs relied more on tools targeting inflows.

2. The use of CBMs has increased in the post-crisis period, as this has become an active policy area. In particular, CBMs have been a common policy tool among EMEs, also within the OECD group. Among EMEs, non-OECD countries have overall been on a liberalising path, while OECD countries have overall become more restrictive on the basis of currency.

3. While the pre-crisis period is characterised by a large use of conventional measures, such as the regulation of the net FX position of banks, other types of CBMs were also increasingly used in the post-crisis period, ranging from taxes on FX liabilities to rules limiting FX derivatives.

4. Despite the declared intent of the measures, tightening actions on net positions of banks, which include the most conventional macro-prudential measures, were less frequent than

\footnotetext{
${ }^{2}$ CBMs encompass a broad category of measures: regulations imposing a different treatment between domestic and FX-denominated operations by banks. CBMs may be addressed at operations amongst residents, or at operations also with non-residents (see page 9 for more information). Within this latter broad category, a sub-set of CMBs may have the character of Capital Flow Management measures (CFMs) as they extend to operations abroad with non-residents. Also, among currency-based CMFs, those measures that apply to operations with non-residents only are traditionally defined as capital controls.

${ }^{3}$ Following the classification of the Morgan Stanley Capital International (MSCI) index, for the purpose of this study EMEs include: Brazil, China, Colombia, Czech Republic, Hungary, India, Indonesia, Korea, Malaysia, Mexico, Philippines, Poland, Russia, South Africa, Thailand and Turkey. Argentina, Costa Rica, Israel and the Slovak Republic have also been included in the group of EMEs, following the categorization of the IMF's World Economic Outlook (WEO).
} 
those on capital inflows and those on assets and liabilities. ${ }^{4}$ This result is striking in light of the finding that all countries claimed that actions were introduced with a macro-prudential purpose. Actions have mostly targeted capital inflows and FX liabilities per se instead of potential imbalances between inflows and outflows or assets and liabilities, which are typically managed by conventional measures on positions.

5. With the exception of China, only countries suffering from original sin (and therefore unable to borrow in domestic currency in international markets) used and tightened CBMs on banks' FX liabilities.

The datasets could be further exploited to advance the assessment of the impact and effectiveness of these measures, a line of work currently still in its infancy. Indeed, while recognising the importance of strengthening prudential national regulations to improve banks' risk management and address broader systemic risk issues, the post-crisis resort to CBMs having the character of CFMs needs to be carefully considered to analyse their overall impact on various variables, including financial openness. While some of these measures may enhance resilience to shocks, analysis on their actual impact and spillover is still limited and inconclusive, due also to important data limitations.

Regardless of their objectives, these measures may also have a number of intended or unintended consequences, ranging from improved financial stability due to a reduction in exchange rate exposure and capital flow volatility, to reduced access to credit or investment opportunities for banks and companies domestically or greater trade imbalances. Consideration should also be given to the potential implications of use of these tools when adopted simultaneously by several or large countries on the functioning of the deep integrated global financial markets. Further research in this area should clarify the role of this class of measures on financial stability and their spillover. Finally, multilateral co-operation is needed to develop a common understanding and agreement on which types of currency-based measures are desirable, macroprudential measures and which have the nature of capital flow management measures and may have an impact on the openness of the financial system overall.

Some of the CBMs included in the datasets that have a CFM character may fall within the scope of operations covered by the OECD Code of Liberalisation of Capital Movements, a legally binding agreement open to adherence to non-OECD countries, but in the paper there is no assessment as to whether any of the measures in the datasets have a bearing on adherents' rights and obligations of this Code.

\footnotetext{
${ }^{4}$ Conventional macro-prudential measures include limits on the net FX position of banks, caps on loan-to-value ratios, debt-service-to-income ratios, etc.
} 


\section{INTRODUCTION AND LITERATURE REVIEW}

\section{Definitional aspects and context}

CBMs encompass a broad category of measures: conceptually, we define them as regulations imposing a different treatment between domestic and FX-denominated operations by banks. This treatment is generally less favourable for operations in FX, compared to domestic currency-denominated ones; however, there are cases where a more stringent requirement has been applied to operations in domestic currency, for instance in the use of reserve requirements differentiated by currency, which may be finetuned by policy-makers at short intervals of time.

CBMs may be addressed at operations amongst residents, or at operations between residents and nonresidents. Within this broad category, a sub-set of CMBs has the character of CFMs, for example when these measures target operations abroad with non-residents. Also, among currency-based CMFs, those restrictions that apply to operations with non-residents only are traditionally defined as traditional capital controls.

The increased use of CBMs in the post-crisis period can be part of countries' regulations to manage capital flows, part of major overhaul of financial sector regulation to address risks arising from high interconnectedness and complexity of large financial institutions, or a combination of both and other aspects. While ongoing regulation has been directed at enhancing the stability of the financial system, it can also have other consequences, such as an impact on the openness and integration of the financial system itself.

This study has been therefore motivated by the interest in understanding trends in the use of CBMs, under the hypothesis that the financial crisis has actually changed the way policy-makers are using these measures. In particular, when starting this research, we wanted to confirm our hypothesis that the use of CBMs has evolved over 2005-2013.

In addition, this study has been motivated by the need of acquiring more granular information on this class of measures, which could be of use to policy-makers, also in light of the fact that most of the existing datasets capture either information on capital controls or on conventional macro-prudential measures. Instead, information on the actual use of CBMs has been limited so far.

\section{Contribution to the literature and structure of the paper}

The increased use of macro-prudential as well as capital flow management measures in the aftermath of the crisis has opened a new - yet still in its infancy - strand of literature that aims at collecting and categorising information on these regulations, creating de jure indices of policy stance and assessing the impact of such policy tools on a range of economic variables, such as credit growth, asset prices, output growth and capital flows (both volumes and composition).

Existing datasets and de jure measures of CFMs and capital controls include the index built by Chinn and Ito (2006), which measures the extent of openness in capital account transactions for 181 countries for the 1970 - 2005 period; Edison and Warnock (2001), who construct a monthly measure of the intensity of capital controls across 29 EMEs based on the degree of restriction on foreign ownership of equities. Information on CFMs has also been collected and categorised in a systematic, cross-country database in Schindler (2009), who constructs an index of financial restrictions in 91 countries for the time period over 
1995-2005; the dataset has been later extended and revised by Klein (2012) and Fernandez et al. (2014). The latest version of Fernandez et al. (2015) covers 100 countries over 1995-2013. Forbes et al. (2015) also construct a new database with detailed information on weekly changes in controls on capital inflows, outflows and macro-prudential measures related to international transactions for 60 countries over 20092011.

Examples of relevant work of data collection on macro-prudential measures include Shim et al. (2013), who construct a database on measures targeting housing markets that covers 60 economies over 1990-2012; this dataset has been extended by Bruno et al. (2015) to include CFM policies that address the spillover of financial conditions through banking sector and bond market capital flows for 12 Asia Pacific economies. Lim et al. (2013) construct a macro-prudential index based on the response to a 2010 IMF survey on Financial Stability and Macroprudential Policy with data covering 39 countries; and Federico et al. (2012) built a dataset on legal reserve requirements for 52 countries over the period 19702011.

In this paper, we contribute to the data collection exercise by constructing two datasets that provide information on CBMs in place in 49 countries in 2005 and on subsequent changes in these regulations over 2005-2013. Some of the measures recorded in our datasets may also feature in other datasets constructed by academics or other international organisations but are classified under different labels-MPMs, CFMs, or others, as for example in Pasricha et al. (2015). It is important to stress the need for a homogenous and standardised dataset on CFMs, MPMs and CBMs, which would provide a basis for a more complete analysis of these forms of financial regulation and their effects on the economy of the countries enacting them as well as possible spillover to other neighbouring or comparable economies.

Our new comprehensive datasets provide information on de jure CBMs disaggregated by several dimensions (e.g. whether the regulations are on inflows, outflows or positions; whether they affect banks' assets, liabilities, positions, derivatives or other; whether they tighten or ease the discrimination between currencies). In addition, consequent adjustments of measures are recorded, which provide additional and granular information on the use of specific measures by a country, with quarterly frequency. This is an important contribution to the existing data collection effort and also allows for a more detailed analysis of CBMs and for monitoring of trends.

Some of the CBMs included in the datasets that have a CFM character may fall within the scope of operations covered by the OECD Code of Liberalisation of Capital Movements, a legally binding agreement open to adherence to non-OECD countries, but in the paper there is no assessment as to whether any of the measures in the datasets have a bearing on adherents' rights and obligations of this Code.

The remainder of the paper is organised as follows: Section II describes the construction of the datasets of CBMs; Section III presents some descriptive trends emerging from the newly constructed datasets; Section IV focuses on a sub-set of measures, those on banks' FX liabilities and assesses their use in countries which are unable to borrow in their domestic currency in international markets; finally, Section V concludes and highlights possible areas of future work. 


\section{CONSTRUCTING THE DATASETS OF CURRENCY-BASED MEASURES}

\section{Country sample}

The sample covers 49 countries: 34 OECD countries, 8 G20 countries which are not OECD members and 7 non-OECD non-G20 countries, which include Thailand, Malaysia, Philippines, Colombia, Costa Rica, Latvia and Lithuania (Annex A). ${ }^{5}$

First, a stocktaking of CBMs in 2005, as reported in the IMF's AREAER 2005, was compiled. This provides an indication of the types of CBMs in place in each country at the starting point of the analysis.

Second, a newly-constructed database recording the changes (introduction, adjustment and removal) in the use of CBMs over 2005- 2013 was compiled. It draws on the replies to an OECD survey conducted in June 2014 to delegates of the Advisory Task Force on the OECD Codes of Liberalisation, and on the measures reported in the IMF's Annual Report on Exchange Arrangements and Exchange Restrictions. These sources were also double-checked with information from other publicly available datasets such as Forbes et al. (2013) and Fernandez et al. (2015). Nevertheless, data contain a high degree of selfjudgement by reporting countries that may affect the quality and consistency of the information provided.

\section{Categories recorded}

In their most disaggregated format, the datasets provide information on 56 categories (Figure 1). The measures have been coded with variables based on the following categories:

i. the country in which the measure took effect;

ii. the date when the measure took effect;

iii. whether the measure adjusts a previous measure;

iv. whether the measure affects banks' assets, liabilities, positions, derivatives or other;

v. whether the measure manages inflows, outflows or positions;

vi. whether it tightens or eases the discrimination between currencies;

vii. the declared intent of the measure-whether it has a prudential and/or a capital control intent;

\footnotetext{
${ }^{5}$ The latter four countries have been selected since they have been invited by the OECD Council to open accession discussions with the Organisation.

${ }^{6}$ For the purpose of this paper, countries are classified between AEs and EMEs as follows: EMEs are defined as those included as emerging market in Morgan Stanley Capital International (MSCI) - namely Brazil, China, Colombia, Czech Republic, Hungary, India, Indonesia, Korea, Malaysia, Mexico, Philippines, Poland, Russia, South Africa, Thailand and Turkey - as well as Argentina, Costa Rica, Israel and the Slovak Republic, have also been included in the group of EMEs, following the categorization of the IMF's World Economic Outlook (WEO).
} 
viii. the operations affected by the measure (shares or other securities of a participating nature; bonds or other debt securities; derivatives and other instruments; credit operations; deposits; others);

ix. whether the measure applies to residents only, non-residents only or both residents and nonresidents;

x. whether, in addition to being applied to banks, the measure is also applied to other financial institutions such as pension funds or insurance companies;

xi. whether the measure has adjustable parameters

This information has been double-checked with the relevant authorities from OECD and non-OECD countries. However, the data has not been "peer-reviewed".

In the dataset on stocktaking, we do not record the initial level of or subsequent changes in intensity of a measure but only whether the measure is in place or not. In the dataset recording changes in the use of CBMs over 2005-2013 we also record if a measure has been adjusted - and the direction of the adjustment (whether tightening or easing) - as well as if new measures have been introduced or existing ones removed, without considering the magnitude of these changes.

However, in practice, some "tightening" actions may be more restrictive than others and some "easing" actions may be more liberalising than others. The difficulty to record the intensity or magnitude of measures has been a standard issue so far in the literature, which has commonly made use of dummy or discrete variables for implementation of new actions or for the existence of a given restriction (see also Zhang and Zoli (2014); Vandenbussche, Vogel and Detragiache (2012); Kuttner and Shim (2013); and Bruno, Shim and Shin (2015)).

Another caveat is that, as only measures from the OECD survey or the IMF AREAER are recorded, the database does not include measures which have been reported in neither of these two sources.

Only measures applying directly on assets, liabilities, positions or derivatives were recorded. Exchange controls, such as Brazil's "Imposto sobre operações financeiras" (IOF) were not recorded. 
Figure 1. The new datasets provide highly disaggregated information covering 56 categories

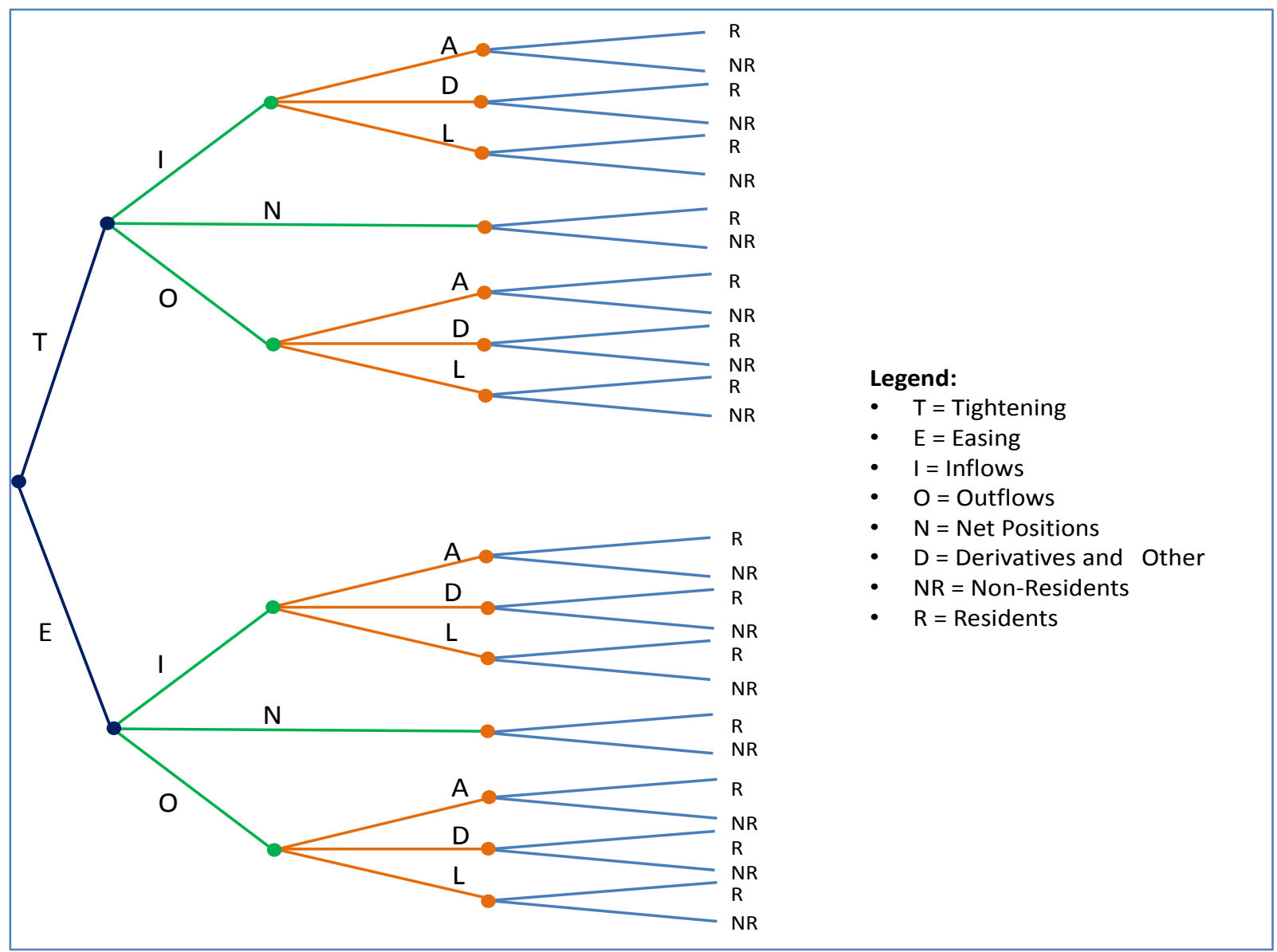

Source: OECD, 2015. 


\section{EVOLUTION IN THE USE OF CURRENCY-BASED MEASURES IN THE POST-CRISIS PERIOD}

\section{CBMs have been a common policy tool among EMEs, also within the OECD group}

We construct a main index of CBMs (CBM index) which takes value of 0 at the beginning of our sample (2004) and considers the cumulative tightening and easing actions over 2005-2013 (Figure 2). Each tightening action constitutes a unitary increment in the index, whereas easing actions constitute unitary decreases of the index. One easing and one tightening action implemented in the same year cancel each other out.

An important caveat is that the CBM index does not take into account the initial level of openness of a country, but instead sets this level at 0 in 2004 for all countries - a similar methodology has been exploited in Zhang and Zoli (2014). This cumulative indicator has its drawbacks, as it only allows making comparisons between trends and directionality in the use of CBMs by countries or groups of countries, but doesn't provide information about relative openness of a country relative to the others. However, it offers an interesting starting point for a focussed discussion on recent trends and directions in the use of CBMs.

EMEs, including some OECD countries, stand out for having been active users of CBMs in 20052013 , with a total of 140 actions recorded, accounting for around of $91 \%$ of total actions recorded in the dataset. Within the EME grouping:

- Non-OECD EMEs (Argentina, Brazil, China, Colombia, Costa Rica, India, Indonesia, Malaysia, Philippines, Russia, South Africa, Thailand) have liberalised their overall CBM stance compared to their 2005 level (28 tightening and 60 easing actions), as existing CBMs have increasingly been removed or eased. As described in Box 1, there has been a general liberalising trend in the use of CBMs by some East Asian countries like Thailand, Malaysia and the Philippines. However, it is to be noted that some of these EMEs have in place capital controls and have probably relied more on these types of tools than on CBMs.

- EMEs, which are also OECD countries (Czech Republic, Hungary, Israel, Korea, Mexico, Poland, Turkey and the Slovak Republic) have been increasingly using CBMs over 20052013 (36 tightening and 17 easing actions).

This evidence points towards the conclusion that CBMs have been a common policy tool among EMEs, also within the OECD group, rather than AEs.

The CBM index for AEs is instead overall stable until 2007 and increases in the post-2008 period: a total of only 12 actions have been implemented by AEs (Austria, Iceland, Latvia and Slovenia) compared to 141 changes implemented by EMEs. Tightening actions by AEs peaked in 2010 .

Finally, G20 countries have increasingly tightened their CBM stance. 
Figure 2. Overall Currency-Based Measure Index - cumulative actions (2004=0)

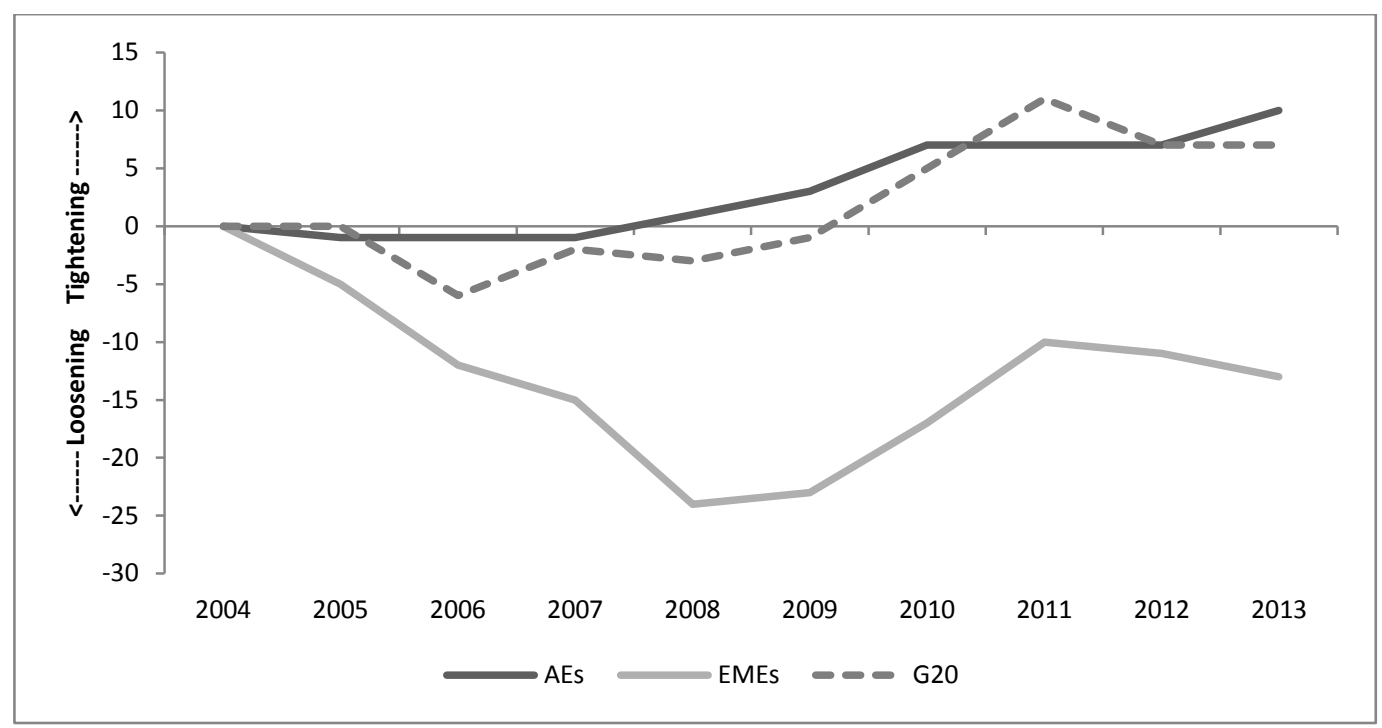

Source: OECD, 2015.

Figure 3 reports the CBM index for a sub-category of measures targeting only banks' FX liabilities. Trends for this specific sub-category are comparable to the overall use of CBMs, with AEs increasingly tightening their regulations on banks' FX liabilities as opposed to EMEs, which instead increasingly liberalised.

EMEs which are also OECD countries (Czech Republic, Hungary, Israel, Korea, Mexico, Poland, Turkey and the Slovak Republic), have been mainly tightening banks' FX liabilities (14 tightening and 11 easing actions). Non-OECD EMEs have been overall on a liberalising trend for these measures (15 tightening and 21 easing actions).

Figure 3. CBM Index for measures targeting FX liabilities of banks - cumulative actions (2004=0)

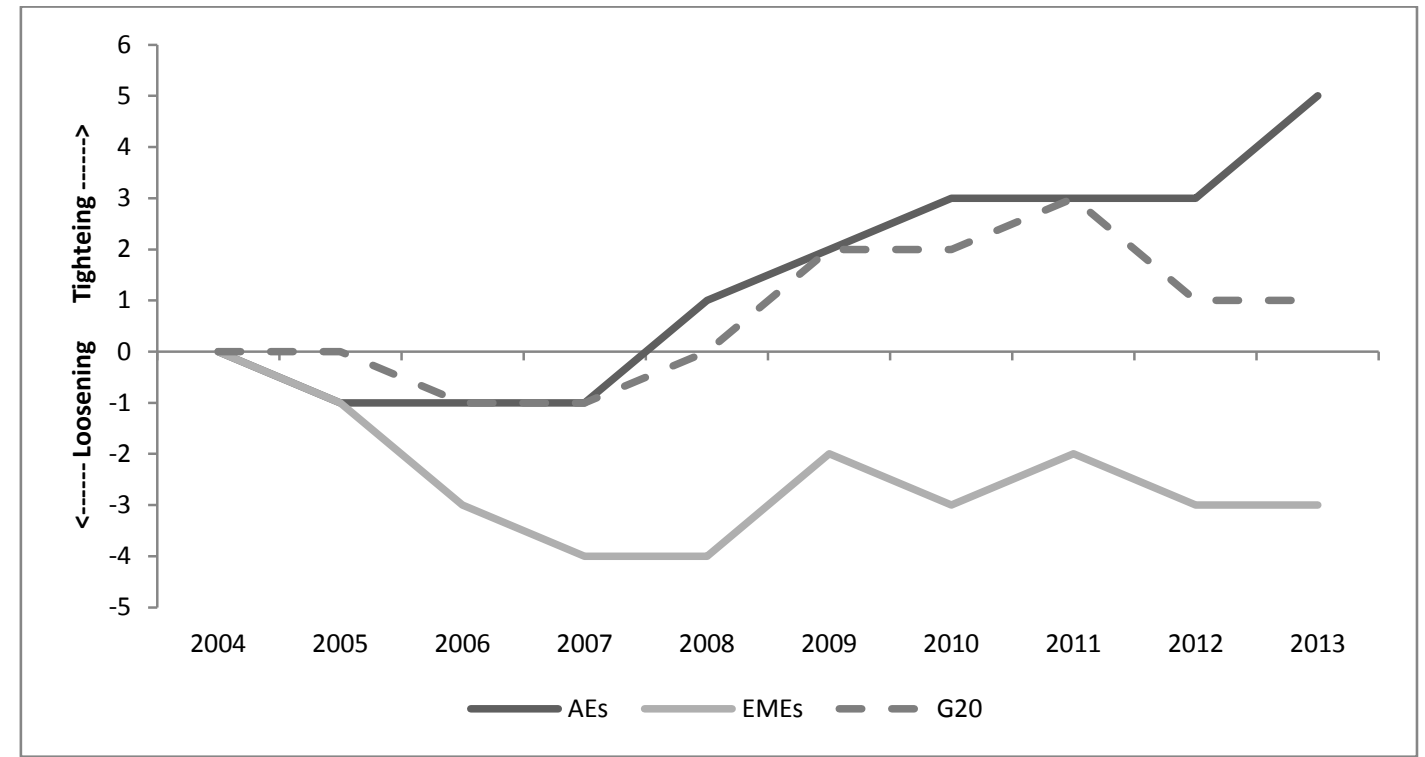




\section{Box 1. The experiences of Malaysia, the Philippines and Thailand}

While the scope of this analysis is limited to OECD countries and G20 non-OECD countries, changes in CBMs were also compiled for Malaysia, the Philippines and Thailand using the IMF's AREAER database. The experience of these countries compared to the other countries in our sample provides some interesting insights.

Firstly, Malaysia, the Philippines and Thailand were particularly active in the use of CBMs over 2005 - 2013. A total of 35 actions were recorded for the three countries, 15 in Malaysia, 8 in the Philippines and 12 in Thailand.

Unlike other countries in our sample, which introduced a mix of easing and tightening actions, Malaysia, the Philippines and Thailand liberalised their CBM's stance over 2005-2013. They only undertook one tightening action each. In contrast, they respectively introduced 14,7 and 11 easing changes.

Actions on financial institutions' assets were more frequent (13 actions), followed by changes on other currencybased measures (8 actions), changes on FX positions (7 actions) and changes on FX liabilities (6 actions),

Malaysia liberalised through incremental steps. For example, several reforms eased lending in FX. In 2005, resident companies were allowed to obtain FX loans up to RM $50 \mathrm{mn}$ - the previous limit was RM $5 \mathrm{mn}$ - and residents were allowed to prepay foreign currency credits. The limit for FX loans of resident companies was further increased in 2007 to RM 100mn. In 2008, limits on residents' borrowing in FX were altogether lifted. Regarding trading in derivatives, Malaysia allowed residents to enter into FX forward contracts with licensed onshore banks under certain conditions. In 2007, forward contracts were further allowed to allow the repayment of foreign credit facilities. In 2010, the limit on FX forward contracts for hedging payments and receipts for currency account transactions was removed.

In the Philippines, some of the liberalising reforms included increasing the scope of banks allowed to invest in FX structured products (2005), allowing rural cooperatives and banks to grant short-term foreign currency loans (2007), easing the limit on the net FX position of banks (2007) and authorising regular banking units to invest in FX debt securities (2011).

In Thailand, most currency-based measures on which actions were taken also included residency criteria. For example, in 2006, the limits on balances on certain foreign currency accounts for residents were increased. Regarding domestic currency accounts for non-residents, they were previously authorised only for settlement purposes and, as of March 2008, they were further authorised for general purposes. There was total of six actions on foreign currency or domestic currency accounts. In 2007, domestic financial institutions were allowed to purchase baht bonds and debentures sold by non-residents and in February 2008 domestic financial institutions were allowed to provide baht liquidity to non-residents without underlying trade or investment in Thailand up to a maximum of B 300 million.

Source : OECD, 2015.

The stance of CBMs targeting inflows, outflows and net positions by AEs and EMEs evolves in an almost symmetrical way. Three AEs (Austria, Iceland, Latvia) in the datasets increasingly tightened measures, whilst EMEs overall eased their regulations on inflows, despite some tightening actions in 20092011. ${ }^{7}$ However, looking at the breakdown within EMEs, four EMEs which are also OECD countries have overall tightened their CBMs on inflows (Hungary, Israel, Korea, Poland).

EMEs eased their regulations on outflows until 2008, introduced some tightening actions in 20092011 and liberalised again in 2012 and 2013; AEs have instead kept their level of regulation on outflows overall stable.

\footnotetext{
${ }^{7}$ Among AEs, Austria implemented the non-binding recommendations of the European Systemic Risk Board (ESRB) which aimed at addressing in a co-ordinated manner the growth of foreign-currency lending to unhedged borrowers; Latvia also introduced a CBM to address the indirect foreign exchange risk arising from lending to unhedged borrowing. Measures by Iceland instead targeted capital inflows as a response to a major domestic crisis.
} 
Finally, the CBM index on banks' net positions shows that EMEs have increasingly relied on an accommodative stance, whereas AEs have tightened their regulations (Figure 4).

Building upon the caveat highlighted above, it is important to remind that no information is provided on the overall level of openness of country groups. Thus, it is likely that, despite the fact that some AEs increasingly tightened their CBMs whilst a sub-group of EMEs have relied on an accommodative stance, AEs are still characterised by more open financial systems compared to these EMEs.

Figure 4. Breakdown of CBM Index on whether the measure manages inflows, outflows or positions, by AEs and EMEs (2004=0)

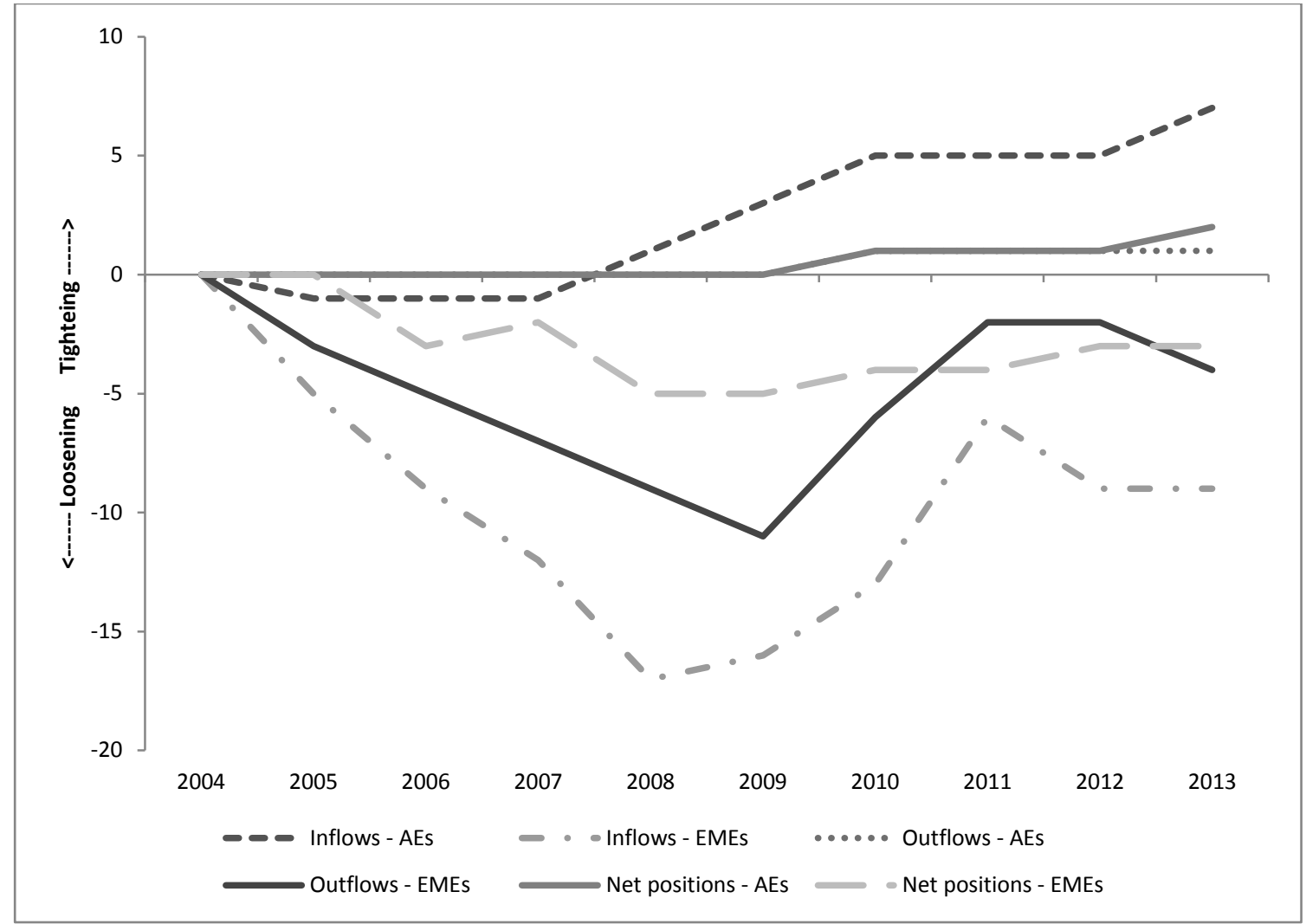

Source: OECD, 2015. 


\section{The starting point: CBMs in place in 2005}

The stocktaking of measures shows that at the starting point of the analysis (2005) EMEs, and in particular non-OECD-countries, were more likely to regulate banks on the basis of the currency of operations than AEs: 79 measures were recorded for EMEs and 13 for AEs. With the only exception of Saudi Arabia, all non-OECD countries had CBMs in place. On the other hand, only 17 OECD countries out of a total of 34 reported CBMs. ${ }^{8}$ A total of 30 measures were recorded in 17 out of 34 OECD countries, an average of 0.9 measure per country, while 33 measures were recorded in the 8 non-OECD G20 countries, an average of 4.1 measures per country. More specifically, great users of CBMs were Indonesia and Philippines, with eight measures recorded in each of these countries, followed by China, Colombia, India and Thailand, with six measures each (Figure 5).

In 2005 measures targeting inflows and net positions were most common in the whole sample, with 50 and 30 occurrences respectively. Measures targeting inflows were twice more frequent as those on outflows. However looking at the breakdown by groups, more than half of the AEs group' measures were targeting banks' net positions, while measures on inflows account for the highest share (49\%) of total in EMEs (Figure 6). ${ }^{9}$ This suggests that in the pre-crisis period AEs used mainly conventional measures on the net position, while EMEs have relied more on tools targeting inflows.

Looking at whether measures regulate banks' balance sheet assets, liabilities, positions or none of these (hereafter referred to as the classes of measures), EMEs were also more likely to regulate banks' assets or liabilities $(56 \%$ of the total, where $21 \%$ of total measures were targeting assets and $35 \%$ liabilities), rather than their FX positions. The opposite was observed in the AEs sample, with $79 \%$ of measures targeting net positions, $21 \%$ of measures targeting liabilities and none targeting assets (Figure 7).

In particular, limits to banks' net open FX positions occurred most frequently, accounting for almost one third of all actions recorded in the stocktaking. Out of a sample of 49 countries, 25 countries reported having a limit on the net FX positions of banks; in addition, currency-matching requirements, which are the equivalent of the limit on the net FX position for other financial institutions, were reported by 25 countries ( 23 OECD and 2 non-OECD countries). ${ }^{10}$

\footnotetext{
${ }^{8}$ While the scope of this note and analysis is limited to currency-based measures directed at banks, some additional information was collected on measures targeting pension funds or insurance companies only. However, these measures are not presented in the note. Nevertheless, it is interesting to note that only seven countries had neither currency-based measures directed at banks nor currency-based measures directed at other financial institutions in 2005: Australia, Canada, Ireland, Israel, Italy, New Zealand and the United States.

${ }^{9}$ The net open foreign exchange position is the sum of all assets and liabilities of the bank which are denominated in foreign exchange.

${ }^{10}$ Only 8 countries in the sample reported neither a limit on the net FX position of banks nor currency-matching requirements.
} 
Figure 5. Distribution of measures by country, 2005

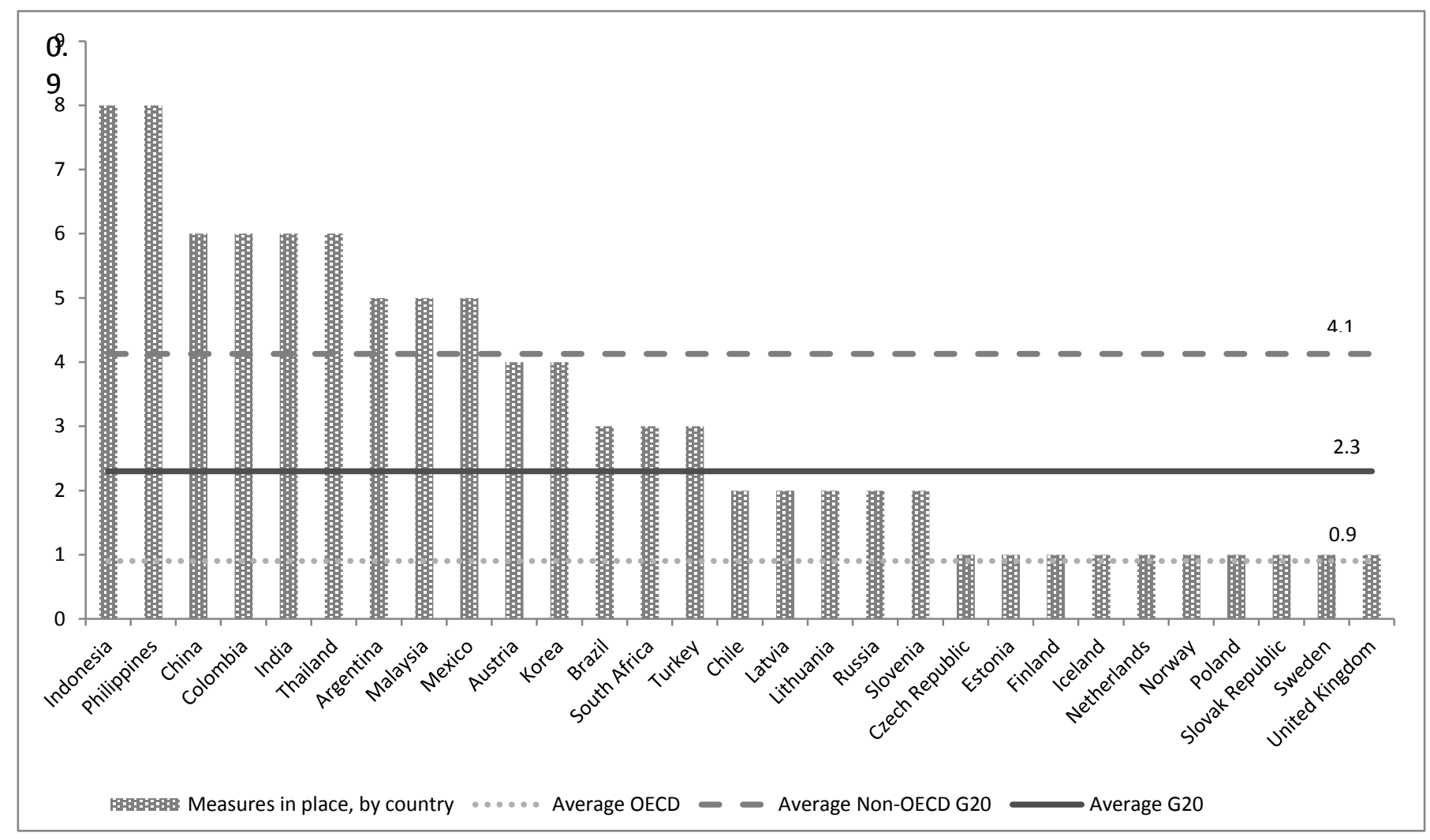

Source: OECD, 2015

Figure 6. Breakdown of measures by type of capital flows managed and country groups, 2005

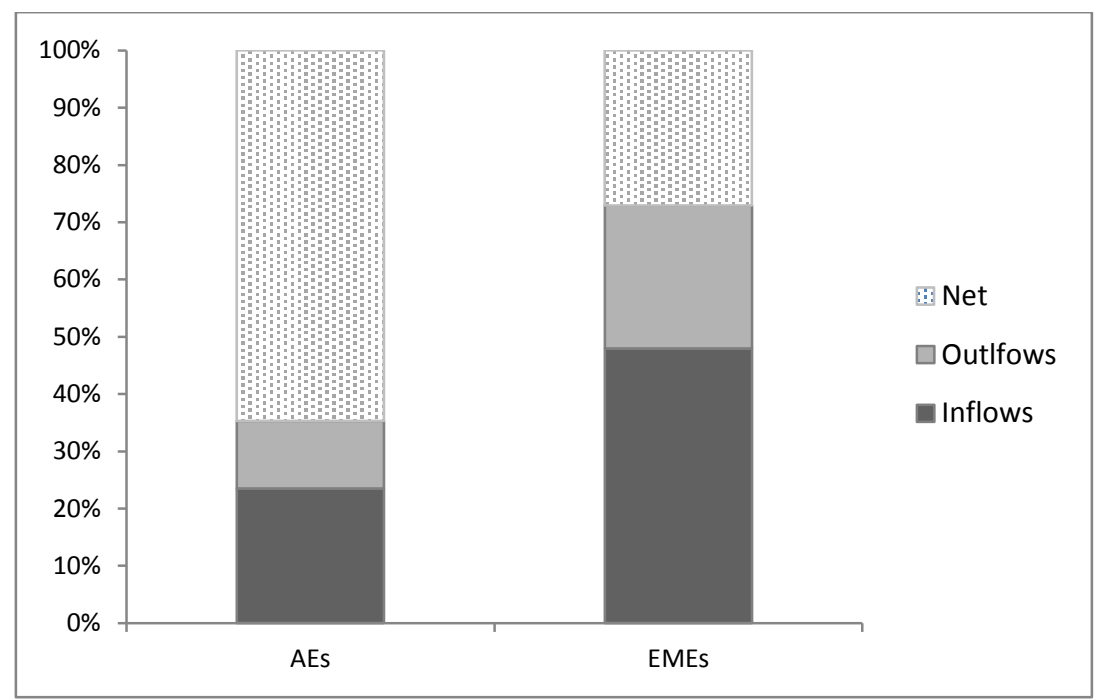

Source: OECD, 2015. 
Figure 7. Breakdown by classes of measures and country groups, 2005

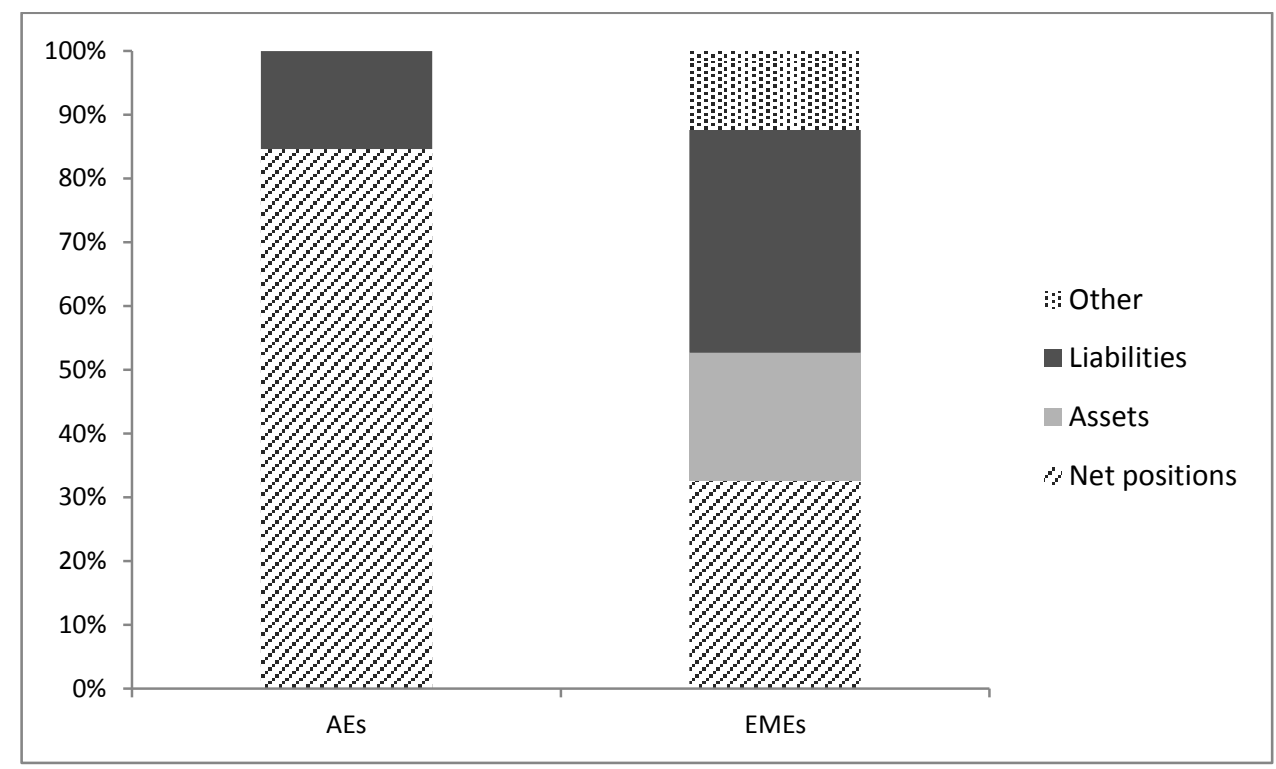

Source: OECD, 2015.

Currency-based measures in place in addition to the common limit on the net FX position of banks, included:

- Differentiated reserve requirements (14\% of total measures): The use of differentiated reserve requirements for domestic and FX deposits was the most frequent measure, used by thirteen countries-Argentina, Austria, China ${ }^{11}$, Colombia, India ${ }^{12}$, Indonesia, Korea, Lithuania, Philippines, Poland, Russia, Slovenia ${ }^{13}$, and Turkey. In some cases, including Austria, China, Indonesia and Slovenia, the reserve requirements have been actually higher for domestic liabilities, as part of a high frequency fine tuning by the central banks that were adjusting reserve requirements on a frequent basis. In other countries, the reserve requirements were higher in $\mathrm{FX}$.

- Rules on FX accounts (10\% of total measures): Rules on FX accounts were also prominent, especially among EMEs, and mainly targeted accounts operated by residents with funds from abroad. For example, in Brazil and Mexico, having an FX account is restricted to certain entities. In Argentina, while authorised banks may open bank accounts in US Dollars or Euros, the approval of the Central Bank is necessary for accounts in other currencies.

\footnotetext{
${ }^{11}$ The reserve requirement was unified for domestic and foreign currency deposits on 15 January 2005.

${ }^{12}$ In India the reserve requirement was the same for rupee and foreign-currency deposits, with the exception of dollar deposits, which had a lower reserve requirement.

${ }^{13}$ The reserve requirement was unified for domestic and foreign currency deposits on 22 February 2005.
} 
- Measures limiting lending in FX (10\% of total measures): Measures limiting lending in FX were also frequent and found in six countries. For instance, in Turkey, banks cannot lend in FX to residents unless they are exporters, investors, entrepreneurs or work in specific businesses.

- Other commonly used instruments include, among others, regulations of trading in FX derivatives (10\% of total measures), liquidity and maturity matching requirements differentiated by currency ( $7 \%$ of total) and regulations of lending in domestic currency to non-residents or of domestic currency accounts operated by non-residents (4\% of total, respectively). ${ }^{14}$

\section{How has the use of CBMs evolved over 2005-2013?}

In the database recording changes in the use of CBMs, 153 actions corresponding to the introduction, adjustment or removal of measures took place in 2005-2013. Around half of the countries in the sample (24 countries out of 49) introduced changes on CBMs over 2005-2013. ${ }^{15}$

More than half of the tightening changes occurred in 2009-2011 and peaked in 2010, while easing actions surged over 2007-2008 (Figure 8).

Distinguishing new measures from adjustments highlights that eleven new CBMs were introduced in 2010. For example, in 2010 Korea introduced six new measures, Iceland put in place three rules in response to its banking crisis and Hungary and Poland implemented policies to limit lending in FX for residents (see Box 2). In addition to the introduction of these measures, eight existing CBMs were tightened in the same year (Figure 8).

\footnotetext{
${ }^{14}$ Liquidity requirements are measures which force banks to put aside liquidity buffers denominated in the same currency of funding; they may be differentiated by currency if the requirements apply differently in FX and domestic currency. Maturity matching requirements are measures which require banks to match the maturity of their assets and liabilities; they may be differentiated by currency if the requirements apply differently in FX and domestic currency.

${ }^{15}$ Whenever the analyses compare different years, only the changes recorded between 2005 and 2013 are considered since the coverage for 2014 is less comprehensive, as one of the sources of information used was not available for 2014 yet, at the time of publishing this paper.
} 
Figure 8. New measures and adjustments, 2005-2013

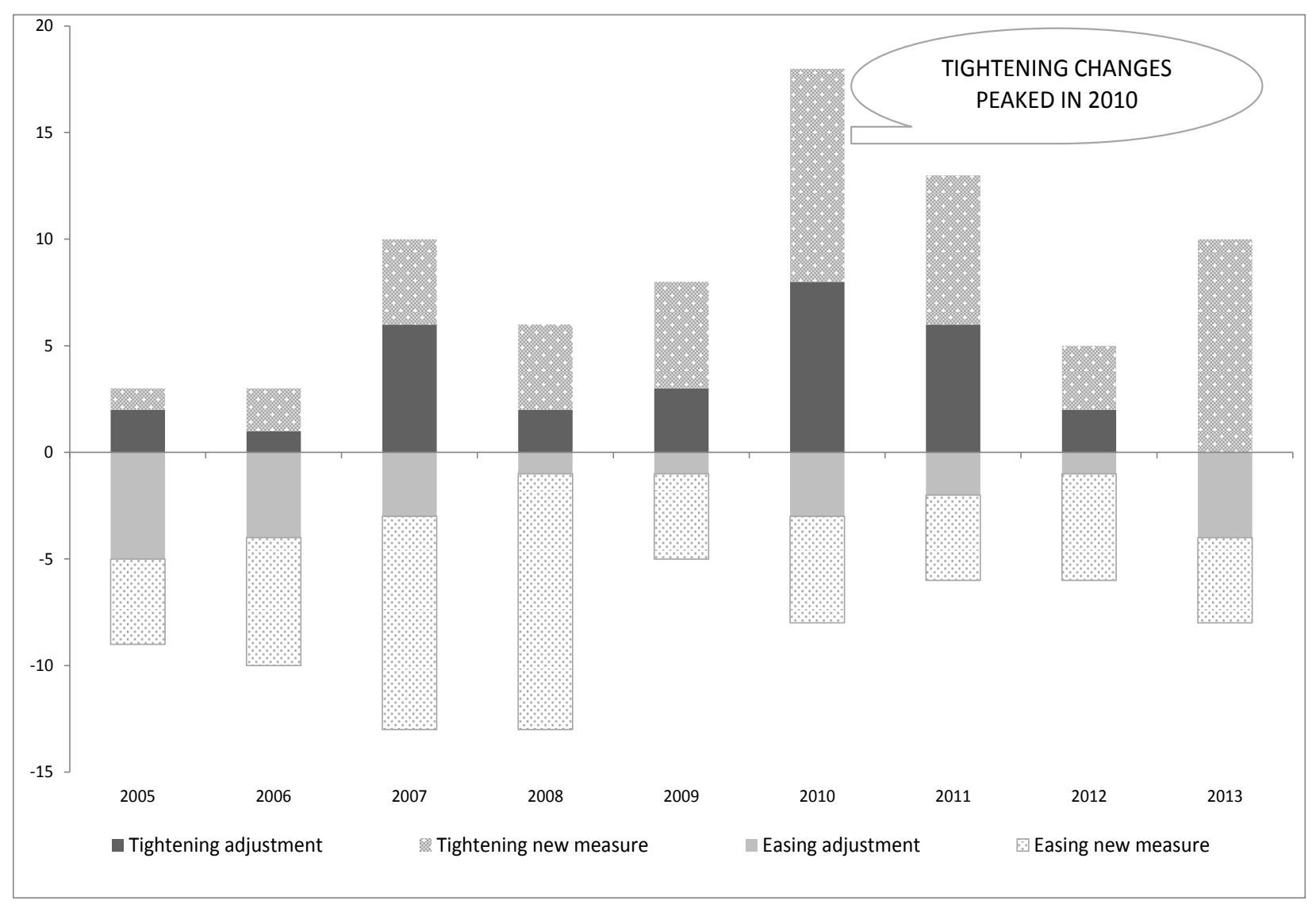

Source: OECD, 2015.

While almost all the non-OECD countries introduced changes, few OECD countries did and most of them are EMEs. We recorded changes in CBMs for all non-OECD countries, with the exception of Saudi Arabia. On the other hand, only 11 OECD countries out of 34 introduced changes: Austria, Hungary, the Czech Republic, Iceland, Israel, Korea, Mexico, Poland, the Slovak Republic, Slovenia and Turkey.

Non-OECD countries enacted a total of 91 changes, which corresponds to an average of 6 per country, while OECD countries enacted 66 changes, an average of roughly 2 per country. However, in practice, OECD countries were split between the 11 countries sub-set that introduced 66 changes and the 23 remaining countries that did not introduce any. If only the sub-set of the OECD countries which took actions on CBMs is considered, then these 11 countries had on average 6 changes per country.

Despite introducing fewer changes on average, eight OECD countries-Austria, Hungary, Iceland, Israel, Korea, Poland, the Slovak Republic and Turkey-out of the eleven that implemented changes on CBMs, increasingly regulated on the basis of the currency of operations. ${ }^{16}$ Indeed, these eight OECD countries put in place more than twice as many tightening actions as easing actions in 2005-2013, while

\footnotetext{
${ }^{16}$ Three OECD countries did not introduce more tightening than easing changes. These are: Czech Republic, which eased its limit on the net FX position of banks; Mexico, which introduced one tightening and one easing measure on FX accounts; and Slovenia, which unified its differentiated reserve requirements.
} 
non-OECD countries have implemented twice as much liberalising than restricting changes. Significant variations exist among the eight OECD countries that overall tightened, as well as within the non-OECD group. Country-specific variations are discussed in more detail subsequently. Of the group of OECD countries that increasingly tightened their regulations, only Austria and Iceland are AEs. Austria in particular stands out for having implemented non-binding recommendations from the ESRB that aimed at addressing in a co-ordinated manner the growth of foreign currency lending to unhedged borrowers.

EMEs have been the greatest users of CBMs, both for tightening and easing actions (Figure 9 and 10). Among EMEs, OECD countries accounted for the largest share of tightening actions in the post-crisis period and especially in 2012 (80\% of total actions), whilst non-OECD EMEs were the most active tighteners in the period 2005-2008. AEs implemented few tightening actions during and in the aftermath of the global crisis but accounted for $40 \%$ of total tightening actions in 2013.

Easing actions have mainly been implemented by EMEs, with the exception of one easing action by Slovenia, which decreased the reserve requirements for FX in 2005. Among EMEs, OECD countries increasingly deregulated in 2007-2012 and non-OECD EMEs accounted for the totality of easing actions in 2013. 
Figure 9. Breakdown of tightening changes by AEs and EMEs (\% of total), 2005-2013

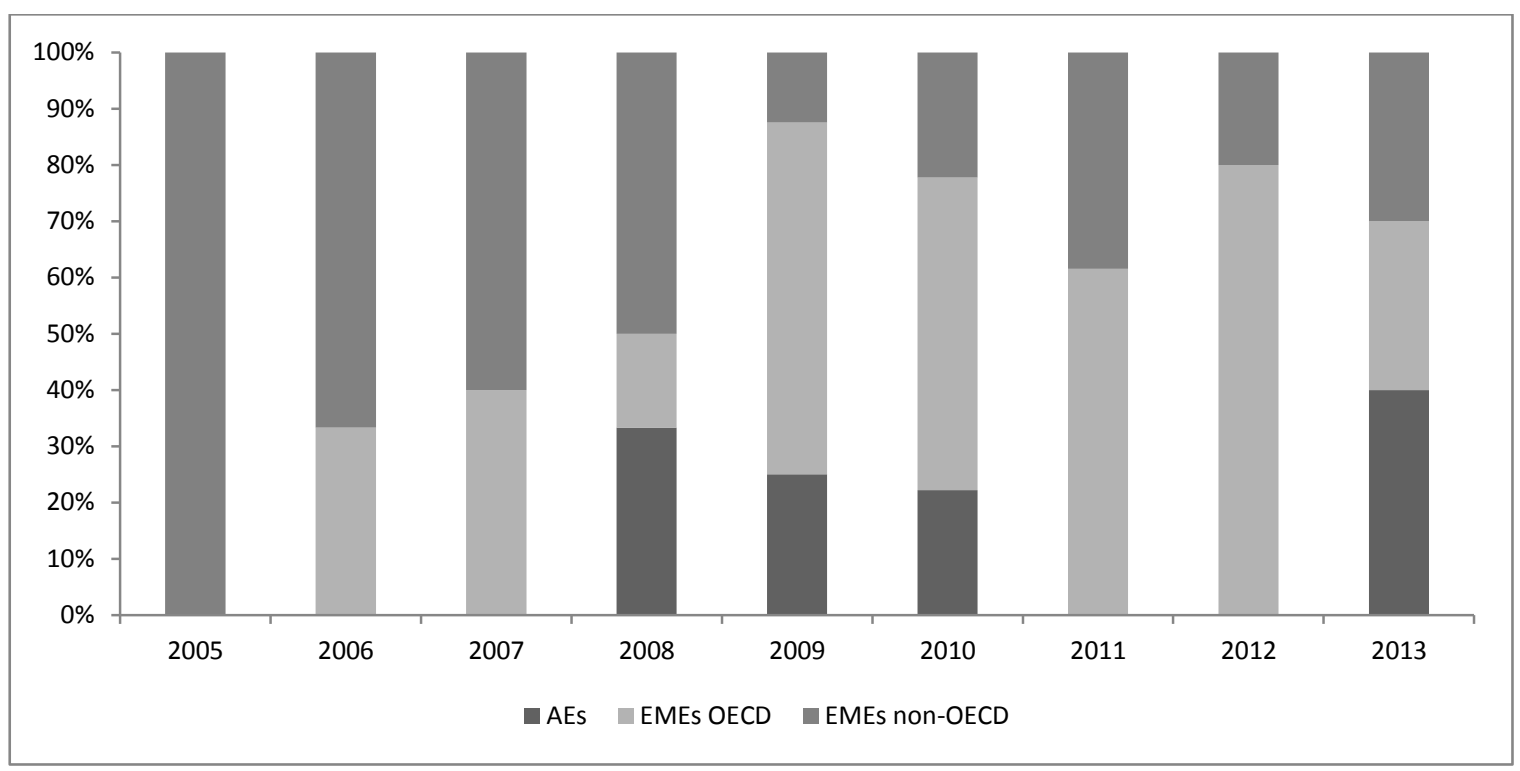

Source: OECD, 2015.

Figure 10. Breakdown of easing changes by AEs and EMEs (\% of total), 2005-2013

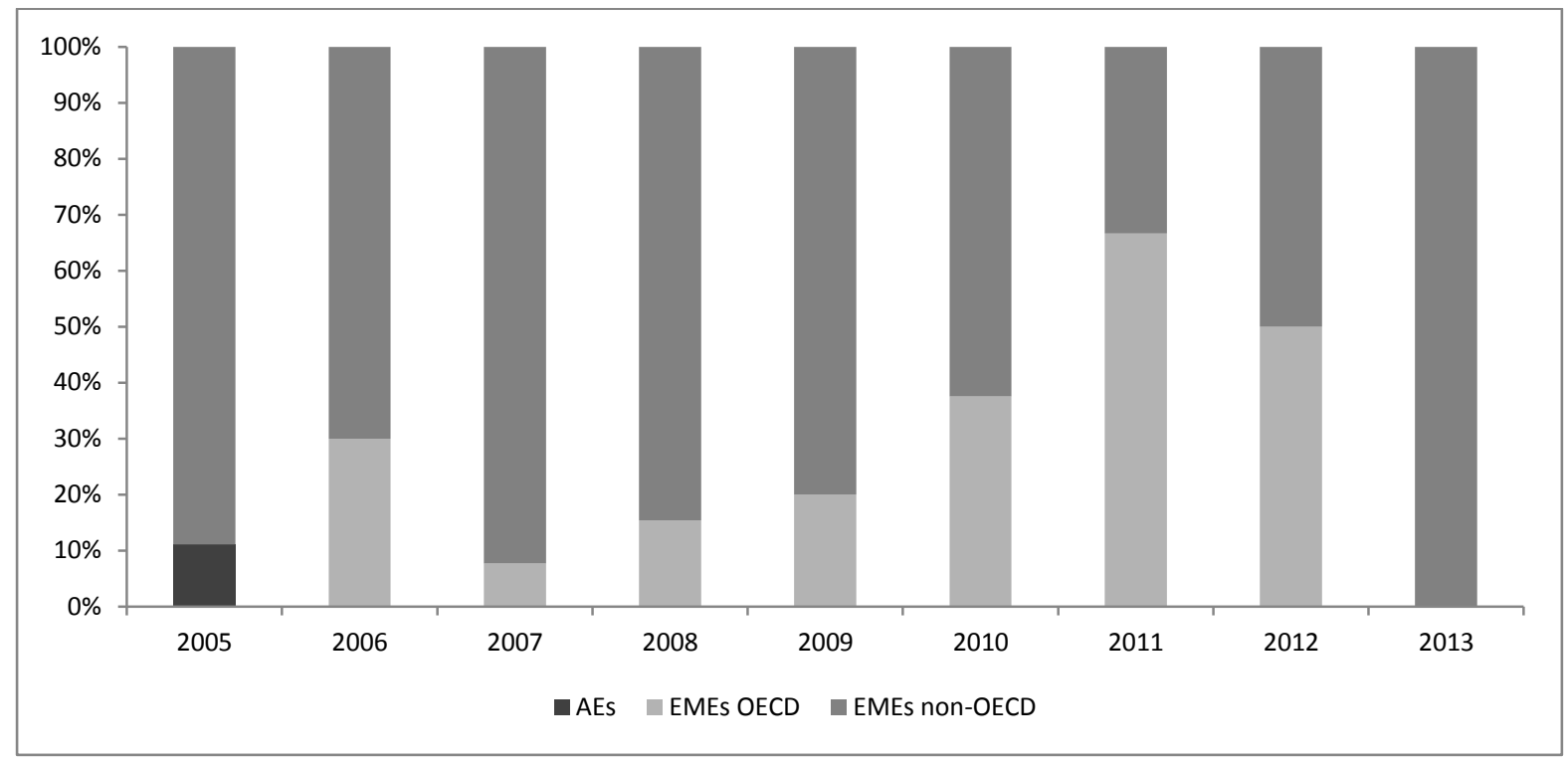

Source: OECD, 2015. 
All countries declared that the introduced or adjusted measures had a macro-prudential intent. While the data for the intended purpose of actions in our database is partially incomplete, only 2 changes in the dataset were declared to have capital control intent. ${ }^{17}$

However, despite the declared intent of the measures, tightening actions on positions, which include the most conventional macro-prudential measures ${ }^{18}$, were less frequent than those on capital inflows and those on assets and liabilities. This result is striking in light of the previous finding that all countries claimed that actions were introduced with a macro-prudential purpose. Actions have mostly targeted capital inflows and liabilities per se instead of potential imbalances between inflows and outflows or assets and liabilities, managed by measures on positions - such as the limit on the net FX position or maturity matching requirements.

The dominance of tightening actions and of measures affecting liabilities in our sample contrasts with the experience of Malaysia and the Philippines, which de-regulated over the past 10 years and where many liberalising actions focused on assets (Box 1).

The categories of measures on which changes occurred most frequently were differentiated reserve requirements, limits on lending in FX, mainly for residential mortgages and to unhedged borrowers, and limits on the net FX position of banks.

Some members of the European Union have implemented some of the European Stability Risk Board (ESRB) non-binding recommendation on lending in foreign currencies ESRB/2011/1, which aim to address in a co-ordinated manner the growth of foreign currency lending to unhedged borrowers (Box 2). For example, to implement the ESRB's recommendations:

- Austria revised its "Minimum Standards on Foreign Currency Loans and Loans with Repayment Vehicles", imposing strict criteria on the granting of new FX loans to private consumers and requiring banks to reduce outstanding FX loans to non-resident banks and branches abroad, in the context of bank retrenchment and as a result of banking reform and recapitalization. In 2013 a new version of this legislation was released, with higher standards.

- Hungary introduced in 2009 a loan-to-value ratio for FX loans and tightened it in 2012. The country further introduced rules for mortgages in FX in 2011; the measure requires monthly gross earnings higher than 15 times the legal minimum wage to obtain a mortgage loan denominated in FX.

- Poland introduced in 2007 a resolution raising risk weight of residential mortgage loans denominated in FX and a subsequent regulation in 2012 introduced a 100\% risk weight for overdue exposures secured by residential property, with the amount of principal or interest instalments depending on changes in exchange rates or foreign currencies other than the borrower's income. Poland has also measures differentiating loan-to-value ratios or debt-toincome requirements for FX loans.

\footnotetext{
${ }^{17}$ Among these, there is a measure introduced by Iceland in 2012 to restrict cross-border capital movements.

18 Common macro-prudential measures include limits on the net FX position of banks, liquidity matching requirements, caps on loan-to-value ratios.
} 


\section{Box 2. The ESRB's recommendation on lending in foreign currencies} currency.

On 21 September 2011, the General Board of the ESRB adopted recommendations on lending in foreign

The recommendations aim to address in a co-ordinated manner the growth of foreign currency lending to unhedged borrowers. In Romania and Estonia, more than $90 \%$ of mortgage loans are issued in foreign currency while in Austria, the share of outstanding mortgage loans in foreign currency is $38 \%$. Policy measures were put in place since 2000 to address the risks associated to foreign currency lending but were often ineffective due to regulatory arbitrage.

More particularly, the ESRB's recommendations' objectives are to:

i. "Limit exposures to credit and market risks [...];

ii. Control excessive foreign currency growth and avoid asset price bubbles;

iii. Limit funding and liquidity risks [...];

iv. Create incentives to improve risk pricing associated with foreign currency lending; and

v. Avoid circumvention of national measures through regulatory arbitrage".

The recommendation ESRB/2011/1 contains seven sub-recommendations, and marked with letters from A to $G$. The recommendations apply only to foreign currency lending to unhedged borrowers, with the exception of recommendation $\mathrm{F}$ which focuses on all foreign currency loans.

Source: OECD, 2015.

Actions tightening lending in FX also took place in some non-EU countries. For example, Iceland prohibited foreign exchange and foreign-exchange-indexed loans to households, as a measure to manage balance of payments pressures resulting from the major banking crisis experienced by Iceland from October 2008 onwards. In 2009, in Turkey foreign currency and foreign-currency-indexed consumer and mortgage credits to residents were forbidden from abroad or from resident banks. ${ }^{19}$

Regulations of lending in domestic currency were implemented in Malaysia and Thailand and targeted lending to non-residents; regulation of domestic currency accounts also mainly targeted accounts operated by non-residents.

The majority of actions targeting banks' FX liabilities were adjustments in differentiated reserve requirements (Box 3). In particular, Turkey and Indonesia adjusted their differentiated reserve requirements 25 and 6 times, respectively. Korea imposed a levy on banks' non-deposit FX liabilities and Iceland imposed a limit on deposit liabilities. China introduced 3 easing actions on accounts in domestic currency operated by non-residents. Domestic currency deposits with non-residents abroad were also regulated.

More than half of the adjustments on the positions of banks were changes in the limits on the net FX positions of banks or on the methods of calculations for the positions and FX cash positions were also

\footnotetext{
${ }^{19}$ In Turkey resident banks may extend credits in foreign exchange that has an average maturity above 1 year and more than 5 million USD or equivalent.
} 
regulated. Other measures recorded include liquidity matching requirements, tightened in Iceland, Korea and Turkey.

The class of measures that accounts for those on derivatives and other measures includes: rules limiting trading in FX derivatives, a limit on the sum of operations in FX that a bank can have and one measure regulating Vostro accounts in Iceland. Other regulations that were implemented by countries in our sample targeted the short or long FX positions or derivatives/off-balance sheet positions.

Rules limiting trading in FX derivatives have been used by Indonesia, Israel, and Korea. In 2005 Indonesia tightened limits on forward contracts against rupiah to non-residents. In 2010 Korea set a maximum derivative trading limit and, in 2011, Israel imposed a reserve requirement for FX derivative transactions by non-residents.

\section{Box 3. Recording changes in differentiated reserve requirements}

Changes to differentiated reserve requirements were particularly frequent and clarifications to explain how they were recorded are provided below.

The measures were deemed to be easing or tightening based on the discrimination on the basis of currency. If the reserve requirement was higher for domestic currency deposits or liabilities, an increase in the reserve requirement for domestic currency deposits or liabilities is considered a tightening.

The methodology allows for "easing cycles" and "tightening cycles" because reserve requirements are frequently adjusted incrementally. The adjustments recorded were the number of easing and tightening cycles- subsequent easing or tightening measures through the adjustment of a parameter- per calendar year. For example, 3 subsequent increases in the reserve requirement for FX deposits in one calendar year would be recorded as only one adjustment. Different parameters adjusted included the reserve requirement, the remuneration of reserves and the ability to carry over excess or deficiency of reserves in a maintenance period.

Source: OECD, 2015 


\section{THE USE OF CURRENCY-BASED MEASURES ON FX LIABILITIES AND CURRENCY RISK}

\section{Only countries suffering from original sin used and tightened measures on FX liabilities}

To complement the information of the datasets we match information on a sub-set of CBMs - those restricting banks' FX liabilities - with data on countries' inability to borrow in domestic currency on international markets, as measured by an original sin index. This also reflects concerns about the risks of borrowing in foreign currency brought up in some EMEs that are not equipped with key-currencies and therefore are exposed to risks of FX liquidity.

\section{Original sin refers to countries' inability to borrow in their domestic currency on foreign markets}

Original sin is a concept developed by Hausmann (1999) and Eichengreen and Hausmann (1999), which refers to a situation where the domestic currency is not used to borrow abroad or in the long term. Countries that have not achieved "redemption" from original sin are unable to borrow in their domestic currency from foreign markets or can only do so to a very small extent. If a country suffers from original sin, its external debt will be mainly denominated in foreign currency. The original sin index has been computed to measure the extent to which a country is unable to borrow in its domestic currency. This index (hereafter named OSIN1), as constructed by Haussmann and Panizza (2010), is based on data on the stock of international debt securities issued by a country in domestic and in foreign currency. Box 4 describes the original sin index used in our analysis. 


\section{Box 4. Original sin index}

To track the evolution of original sin across our sample, we use one of the three indicators developed by Eichengreen, Haussman and Panizza (2005).

Our indicator of original $\sin (\mathrm{OSIN1})$ is computed as one minus the ratio of the stock of international securities issued by a country in its own currency to the total stock of international securities issued by the country. The formula for OSIN1 is as follows:

$$
\text { OSIN } 1=1-\frac{\text { debt securities issued by country } i \text { in currency } i}{\text { total debt securities issued by country } i}
$$

The index ranges between 0 and 1 , where 0 indicates that the country has only issued debt securities abroad in its domestic currency and 1 indicates that the country has only issued debt securities abroad in foreign currency.

OSIN1 has two drawbacks:

- It covers debt securities only and does not include other types of debt;

- It does not take into account opportunities for hedging currency exposures through swaps;

For an attempt to build a more comprehensive index, see Eichengreen, Hausmann, and Panizza (2005). Haussmann and Panizza (2010) also built an index, labelled INDEXA, which captures the scope of hedging currency exposures through swaps.

Source: Adapted from Haussman and Panizza, (2010).

The average original sin indices over 2005-2013 for a smaller sample of 40 countries, including OECD and G20 countries, have been computed with data on international debt securities collected by the Bank of International Settlements (BIS) and are presented in Annex B (for the indices across years).

Eighteen countries out of forty in the sample have not achieved redemption from original sin, if redemption from original sin is considered to be achieved when OSIN1 is below 0.85, based on Haussmann and Panizza's contribution (2010). In addition, 24 out of these 40 countries have an index higher than 0.5, which means that they borrow predominantly in foreign currency. All seven non-OECD G20 countries in the sample for which data are available have an original sin index higher than $0.5 .^{20}$

Looking at developing countries, Haussman and Panizza (2010) found that, "given original sin, abstinence [i.e. the reduction in the net debt] is a better strategy than indebtedness: foreign currency debt is too risky to be sensible, given the mismatches it generates and since countries are unable to borrow without creating currency mismatches they have opted to forgo net borrowing." The authors conclude that "fewer countries are willing to put themselves in a position of having to borrow abroad" and in foreign currency.

We observe that countries suffering from original sin have made use of CBMs. Trends in the use of CBMs echo Haussmann and Panizza's finding that developing countries suffering from original sin have sought to reduce foreign currency debt. CBMs on banks' FX liabilities can reduce FX debt by increasing

\footnotetext{
${ }^{20}$ No data were available for Indonesia and New Zealand.
} 
the cost of holding FX liabilities or by imposing direct limits on their quantity. ${ }^{21}$ For example, differentiated reserve requirements with higher reserve requirements for FX deposits, limits on FX liabilities and levies on FX liabilities constitute disincentives to the holding of FX liabilities by making it costlier or altogether forbidden past a certain threshold.

Only countries with an OSIN1 higher than 0.85 and China used CBMs limiting FX liabilities. More specifically, while not all the countries that suffer from original sin used measures limiting FX liabilities, they were more likely to do so than countries that are able to borrow in their domestic currency, according to the analysis of the databases. In the group of countries that had an OSIN1 lower than 0.85 and had achieved redemption, only 2 measures, in force in China in 2005, and no adjustment limiting FX liabilities were recorded (Figure 11).

\section{Figure 11. With the exception of China, only countries suffering from original sin used and tightened CBMs on} banks' FX liabilities

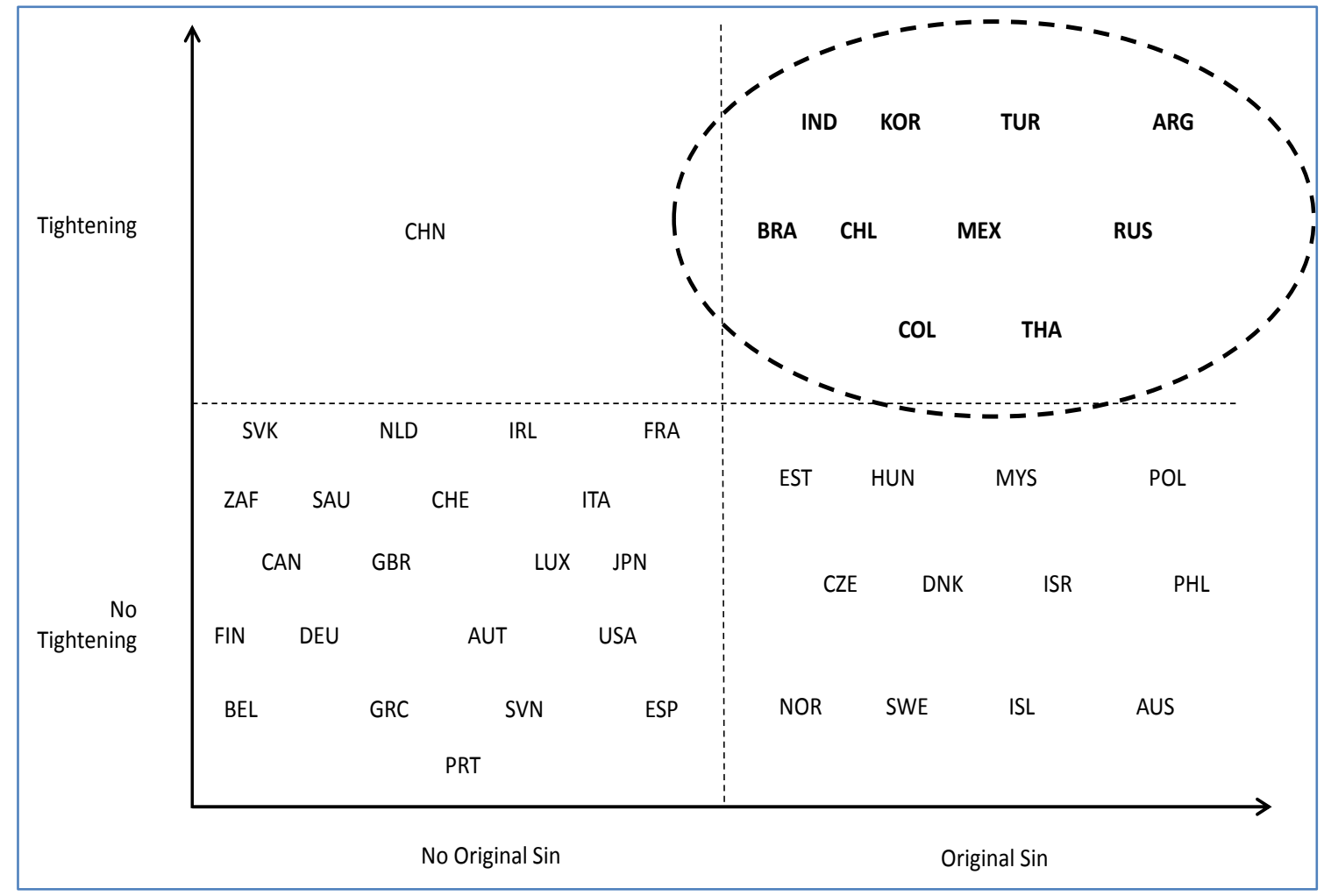

Source: OECD, 2015.

\section{Beyond their macro-prudential declared intent, these measures could impact capital flows}

As previously mentioned, all measures that belong to this subset of CBMs targeting banks' FX liabilities have a self-declared macro-prudential intent, according to the authorities. However, they could also have an impact on capital flows since the countries that use them are unable to borrow in their

${ }^{21}$ Countries may resort to residency-based measures to limit external borrowing altogether. Leaving aside China and India which still maintain extensive residency based measures on capital flows, other countries in the sample do not resort to extensive use of such measures. 
domestic currency on international markets. This could make this sub-set of currency-based measures limiting FX liabilities equivalent to residency-based CFMs.

More specifically, measures regulating banks' FX liabilities in countries that suffer from original sin could have a range of intended and unintended consequences that will depend on the features of the measures and of the country enacting it:

i. First, measures limiting specific types of FX liabilities could change the structure of capital inflows without necessarily reducing them.

ii. Second, the measures could increase borrowing in domestic currency, as it may become a viable alternative in some countries.

A third option is that the measures will reduce external liabilities, that is, liabilities to non-residents. This may occur because countries limiting banks' liabilities in FX are limiting borrowing on international markets altogether if they are unable to borrow abroad in their domestic currency. Further analysis could focus on the impact of CBMs targeting FX liabilities on the external debt of banks, defined as debt in the hands of non-residents. 


\section{CONCLUSIONS AND POSSIBLE AREAS OF FUTURE WORK}

The paper reviewed the use of currency-based measures in the pre- and post-crisis period in a sample of 49 countries. While AEs generally had few CBMs in place at the starting point of the analysis (2005), only few of them gradually tightened their CBM stance over time, mainly over 2009-2011. In general however, EMEs, including OECD countries, have been the most active users of CBMs. While some of the measures implemented represent conventional macro-prudential policies such as limits on the net FX position of banks, other types of measures were also used, ranging from taxes on FX liabilities to rules limiting FX derivatives.

Given the increasing propensity to use CBMs by some countries emerging from the analysis, future research should seek to better understand the impact of these measures and also of different classes of measures within and across countries, as well as their spillover effects. The literature in this area is still in its infancy and these databases aim at providing useful information supporting further empirical research. However, additional datasets, such as comprehensive inventories of capital controls, prudential measures and CBMs need to be collected in a more systematic and comparable way.

While the actions recorded in the databases were all declared to have a macro-prudential intent, this does not preclude that they may have an impact on capital flows, for instance curbing intra-bank lending in FX. Further research in this area should clarify the role of this class of measures on financial stability and their spillover effects.

Finally, multilateral co-operation is needed to develop a common understanding and agreement on which types of currency-based measures are desirable, macro-prudential measures and which have the nature of capital flow management measures and may have an impact on the openness of the financial system overall. 


\section{BIBLIOGRAPHY}

Baba, C. and A. Kokenyne, 2011. "Effectiveness of Capital Controls in Selected Emerging Markets in the 2000s". IMF Working Paper, WP/11/281.

Beirne, J. and C. Friedrich, 2014. "Capital Flows and Macroprudential Policies - A Multilateral Assessment of Effectiveness and Externalities". European Central Bank Working Paper Series, No. 1721.

Bruno, V., I. Shim and H. S. Shin, 2015. "Comparative Assessment of Macroprudential Policies”. BIS Working Paper, No. 502.

Chinn, M. D. and H. Ito, 2006. "What Matters for Financial Development? Capital Controls, Institutions, and Interactions". Journal of Development Economics, Volume 81, Issue 1, Pages 163-192 (October).

Edison, H. J. and F. E. Warnock, 2001. "A Simple Measure of the Intensity of Capital Controls". IMF Working Paper Series, WP/01/180.

Eichengreen, B., R. Hausmann, and U. Panizza, 2002. "Original Sin: The Pain, the Mystery and the Road to Redemption. Paper presented at a conference on Currency and Maturity Matchmaking: Redeeming Debt from Original Sin”, Inter-American Development Bank.

Eichengreen, B., R. Hausmann, and U. Panizza, 2005. "The Pain of Original Sin, in Other People's Money”. B. Eichengreen and R. Hausmann (eds.), Chicago University Press, Chicago.

Federico, P., C. Vegh and G. Vuletin, 2012. "Reserve Requirement Policy over the Business Cycle". Manuscript, available at www.cass.city.ac.uk/_data/assets/pdf_file/0016/171106/3.-Federico-v2.pdf (accessed 7 July 2015).

Fernández, A., A. Rebucci and M. Uribe, 2014. “Are Capital Controls Countercyclical?”. New York, United States: Columbia University. Mimeographed document.

Fernández, A., M. W. Klein, A. Rebucci, M. Schindler and M. Uribe, 2015. "Capital Control Measures: A New Dataset". IMF Working Paper, WP/15/80.

Forbes, K., M. Fratzscher and R. Straub, 2015. "Capital Flow Management Measures: What Are They Good For?”. NBER Working Paper Series, No. 20860.

Hausmann, R. and U. Panizza, 2010. "Redemption or Abstinence? Original Sin, Currency Mismatches and Counter-Cyclical Policies in the New Millenium". Center for International Development Working Paper, No. 194, Harvard University.

International Monetary Fund (IMF), 2011. "Macroprudential Policy: An Organizing Framework". Prepared by the Monetary and Capital Markets Department. 
IMF. AREAER Online. International Monetary Fund, available at http://stg-elibrary-areaer.imf.org/Areaer/Pages/Home.aspx.

IMF, 2015. "Measures which are Both Macroprudential and Capital Flow Management Measures: IMF Approach". Report to G20 Finance Ministers, available at https://g20.org/wpcontent/uploads/2015/05/Measures-which-are-Both-Macro-prudential-and-Capital-FlowManagement-Measures-IMF-Approach-April-2015.pdf (accessed 7 July 2015).

Klein, M. W., 2012. "Capital Controls: Gates versus Walls”. Brookings Papers on Economic Activity 2012 (Fall): 317-355.

Kuttner, K. N. and I. Shim, 2013. "Can non-interest rate policies stabilise housing markets? Evidence from a panel of 57 economies". BIS Working Paper Series No. 433

Lim, C., I. Krznar, F. Lipinsky, A. Otani and X. Wu, 2013. "The Macroprudential Framework: Policy Responsiveness and Institutional Arrangements”. IMF Working Paper WP/13/166.

Organisation for Economic Co-operation and Development (OECD), 2013. OECD Codes of Liberalisation of Capital Movements. www.oecd.org/daf/inv/investment-policy/codes.htm

OECD, 2013. OECD Codes of Liberalisation of Current Invisible Operations. www.oecd.org/daf/inv/investment-policy/codes.htm

OECD, 2015. "The OECD's Approach to Capital Flow Management Measures Used with a MacroPrudential Intent". Report to G20 Finance Ministers, available at www.oecd.org/g20/topics/tradeand-investment/G20-OECD-Code-Report-2015.pdf (accessed 7 July 2015).

Pasricha, P., M. Falagiarda, M. Bijsterbosch and J. Aizenman, 2015. "Domestic and Multilateral Effects of Capital Controls in Emerging Markets”. NBER Working Paper Series, No. 20822.

Schindler, M., 2009. “Measuring Financial Integration: A New Dataset”. IMF Staff Papers 56(1):222-38.

Shim, I., B. Bogdanova, J. Shek and A. Subelyte, 2013. "Database for Policy Actions on Housing Markets”. BIS Quarterly Review, September, 83-95.

Vandenbussche, J., U. Vogel and E. Detragiache, 2012. "Macroprudential Policies and Housing Price: A New Database and Empirical Evidence for Central, Eastern, and Southeastern Europe". IMF Working Paper WP/ 12/303

Zhang, L. and E. Zoli, 2014. "Leaning Against the Wind: Macroprudential Policy in Asia". IMF Working Paper WP/14/22. 
ANNEX A. COUNTRY COVERAGE OF THE DATASETS

Table A.1. Country coverage

\begin{tabular}{|l|l|l|}
\hline Country & OECD - Member & G20 - Member \\
\hline Argentina & No & Yes \\
\hline Australia & Yes & Yes \\
\hline Austria & Yes & No \\
\hline Belgium & Yes & No \\
\hline Brazil & No & Yes \\
\hline Canada & Yes & Yes \\
\hline Chile & Yes & No \\
\hline China & No & Yes \\
\hline Colombia & No & No \\
\hline Costa Rica & No & No \\
\hline Czech Republic & Yes & No \\
\hline Denmark & Yes & No \\
\hline Estonia & Yes & No \\
\hline Finland & Yes & No \\
\hline France & Yes & Yes \\
\hline Germany & Yes & Yes \\
\hline Greece & Yes & No \\
\hline Hungary & Yes & No \\
\hline Iceland & Yes & No \\
\hline India & No & Yes \\
\hline Indonesia & No & Yes \\
\hline Ireland & Yes & No \\
\hline Israel & Yes & No \\
\hline Italy & Yes & Yes \\
\hline Japan & Yes & Yes \\
\hline Korea & Yes & Yes \\
\hline Latvia & No & No \\
\hline Luxembourg & Yes & No \\
\hline Malaysia & No & No \\
\hline Mexico & Yes & Yes \\
\hline Netherlands & Yes & No \\
\hline New Zealand & Yes & \\
\hline Norway & & No \\
\hline Philippines & No & \\
\hline
\end{tabular}




\begin{tabular}{|l|l|l|}
\hline Country & OECD - Member & G20 - Member \\
\hline Poland & Yes & No \\
\hline Portugal & Yes & No \\
\hline Russia & No & Yes \\
\hline Saudi Arabia & No & Yes \\
\hline Slovak Republic & Yes & No \\
\hline Slovenia & Yes & No \\
\hline South Africa & No & Yes \\
\hline Spain & Yes & No \\
\hline Sweden & Yes & No \\
\hline Switzerland & Yes & No \\
\hline Thailand & No & No \\
\hline Turkey & Yes & Yes \\
\hline United Kingdom & Yes & Yes \\
\hline United States & Yes & Yes \\
\hline
\end{tabular}

Source: OECD, 2015. 


\section{ANNEX B. ORIGINAL SIN INDICES}

Table B.1. Original sin indices (OSIN1)

2005-2013 and Average

\begin{tabular}{|c|c|c|c|c|c|c|c|c|c|c|}
\hline & 2005 & 2006 & 2007 & 2008 & 2009 & 2010 & 2011 & 2012 & 2013 & Average \\
\hline Argentina & 0.991 & 0.992 & 0.992 & 0.993 & 0.992 & 0.994 & 0.995 & 0.997 & 0.998 & 0.994 \\
\hline Australia & 0.877 & 0.882 & 0.875 & 0.881 & 0.875 & 0.870 & 0.869 & 0.870 & 0.884 & 0.876 \\
\hline Austria & 0.367 & 0.353 & 0.328 & 0.312 & 0.288 & 0.279 & .273 & 264 & 0.235 & 0.300 \\
\hline Belgium & 0.182 & 0.191 & 0.177 & 0.121 & 0.109 & 0.110 & .095 & 0.090 & .117 & 0.132 \\
\hline Brazil & 0.987 & 0.963 & 0.907 & 0.900 & 0.900 & 0.916 & .914 & 0.920 & 0.926 & 0.926 \\
\hline Canada & 0.732 & 0.702 & 0.670 & 0.654 & 0.646 & 0.623 & 0.632 & 0.676 & 0.742 & 0.675 \\
\hline Chile & & & & 1.000 & & & 0.953 & 0.953 & 0.961 & 0.967 \\
\hline China & & & & & 0.789 & 0.749 & 0.695 & 0.497 & 0.495 & 0.645 \\
\hline Czech Republic & & & 0.992 & 0.997 & & 0.984 & 0.980 & 0.972 & 0.975 & 0.984 \\
\hline Denmark & 0.986 & 0.990 & 0.991 & 0.988 & 0.992 & 0.996 & 0.999 & 0.983 & 0.983 & 0.990 \\
\hline Estonia & 1.000 & 1.000 & 1.000 & 1.000 & 1.000 & 1.000 & 1.000 & 1.000 & 1.000 & 1.000 \\
\hline Finland & 0.244 & 0.243 & 0.292 & 0.337 & 0.396 & 0.481 & 0.472 & 0.430 & 0.430 & 0.369 \\
\hline France & 0.244 & 0.237 & 0.229 & 0.219 & 0.230 & 0.243 & 0.246 & 0.242 & 0.249 & 0.238 \\
\hline Germany & 0.333 & 0.323 & 0.316 & 0.318 & 0.337 & 0.373 & 0.394 & 0.432 & 0.444 & 0.363 \\
\hline Greece & 0.167 & 0.116 & 0.101 & 0.095 & 0.065 & 0.043 & 0.030 & 0.036 & 0.030 & 0.076 \\
\hline Hungary & & & 1.000 & 1.000 & 1.000 & 1.000 & 1.000 & 1.000 & 1.000 & 1.000 \\
\hline Iceland & 0.926 & 0.930 & 0.921 & 0.910 & 0.935 & 0.927 & 0.915 & 0.909 & 0.903 & 0.920 \\
\hline India & & & & 0.997 & 0.996 & 0.995 & 0.995 & 0.993 & 0.994 & 0.995 \\
\hline Ireland & 0.271 & 0.289 & 0.293 & 0.268 & 0.239 & 0.239 & 0.224 & 0.233 & 0.234 & 0.254 \\
\hline Israel & & & 0.995 & 0.995 & 0.996 & 0.994 & 0.990 & 0.990 & 0.990 & 0.993 \\
\hline Italy & 0.195 & 0.158 & 0.123 & 0.095 & 0.074 & 0.075 & 0.069 & 0.067 & 0.066 & 0.102 \\
\hline Japan & 0.419 & 0.448 & 0.422 & 0.361 & 0.354 & 0.377 & 0.427 & 0.514 & 0.635 & 0.440 \\
\hline Korea & 1.000 & 1.000 & & 1.000 & & & & & 0.998 & 0.999 \\
\hline Luxembourg & 0.439 & 0.443 & 0.437 & 0.434 & 0.440 & 0.455 & 0.462 & 0.489 & 0.510 & 0.457 \\
\hline Mexico & & 0.984 & 0.958 & 0.947 & 0.954 & 0.950 & 0.953 & 0.951 & 0.932 & 0.954 \\
\hline Netherlands & 0.292 & 0.304 & 0.302 & 0.288 & 0.272 & 0.285 & 0.296 & 0.318 & 0.319 & 0.297 \\
\hline Norway & 0.970 & 0.977 & 0.984 & 0.973 & 0.925 & 0.918 & 0.923 & 0.928 & 0.940 & 0.949 \\
\hline Poland & & & & 1.000 & & & & & 0.995 & 0.998 \\
\hline Portugal & 0.062 & 0.043 & 0.028 & 0.018 & 0.020 & 0.029 & 0.027 & 0.031 & 0.032 & 0.032 \\
\hline Russia & & 0.994 & 0.976 & 0.973 & 0.981 & 0.983 & 0.946 & 0.941 & 0.948 & 0.968 \\
\hline Saudi Arabia & 0.806 & 0.936 & 0.952 & 0.962 & 0.820 & 0.703 & 0.625 & 0.609 & 0.631 & 0.783 \\
\hline Slovak Republic & 0.069 & & & & & & & & 0.238 & 0.154 \\
\hline Slovenia & 0.008 & & & & & 0.038 & 0.035 & 0.120 & 0.492 & 0.139 \\
\hline South Africa & 0.845 & 0.814 & 0.803 & 0.821 & 0.813 & 0.816 & 0.862 & 0.863 & 0.875 & 0.835 \\
\hline Spain & 0.108 & 0.114 & 0.132 & 0.130 & 0.125 & 0.123 & 0.102 & 0.088 & 0.079 & 0.111 \\
\hline Sweden & 0.953 & 0.941 & 0.932 & 0.914 & 0.886 & 0.874 & 0.857 & 0.848 & 0.857 & 0.896 \\
\hline Switzerland & 0.799 & 0.845 & 0.860 & 0.806 & 0.707 & 0.633 & 0.578 & 0.592 & 0.689 & 0.723 \\
\hline Turkey & & & & & & & & & 0.989 & 0.989 \\
\hline United Kingdom & 0.671 & 0.670 & 0.688 & & 0.623 & 0.625 & 0.630 & 0.630 & 0.619 & 0.645 \\
\hline United States & 0.274 & 0.321 & 0.393 & 0.415 & 0.403 & 0.377 & 0.382 & 0.345 & 0.330 & 0.360 \\
\hline
\end{tabular}

Source: OECD calculations based on BIS (2014) data on international debt securities. 


\section{LIST OF OECD WORKING PAPERS ON INTERNATIONAL INVESTMENT \\ www.oecd.org/daf/inv/investment-policy/working-papers.htm}

2015

2015/2 Investment Treaties over Time - Treaty Practice and Interpretation in a Changing World

2015/1 The Policy Landscape for International Investment by Government-Controlled Investors: A Fact Finding Survey

2014

2014/3 Investment Treaties and Shareholder Claims: Analysis of Treaty Practice

2014/2 Investment Treaties and Shareholder Claims for Reflective Loss: Insights from Advanced Systems of Corporate Law

2014/1 Investment Treaty Law, Sustainable Development and Responsible Business Conduct: A Fact Finding Survey

2013

2013/4 Temporal validity of international investment agreements: a large sample survey of treaty provisions

2013/3 Investment treaties as corporate law: Shareholder claims and issues of consistency

2013/2 Lessons from Investment Policy Reform in Korea

2013/1 China Investment Policy: an Update

2012

2012/3 Investor-state dispute settlement: A scoping paper for the investment policy community

2012/2 Dispute settlement provisions in international investment agreements: A large sample survey

2012/1 Corporate greenhouse gas emission reporting: A stocktaking of government schemes

2011

2011/2 Defining and measuring green FDI: An exploratory review of existing work and evidence

2011/1 Environmental concerns in international investment agreements: a survey

2010

2010/3 OECD's FDI Restrictiveness Index: 2010 Update

2010/2 Foreign state immunity and foreign government controlled investors

2010/1 Intellectual property rights in international investment agreements

2006

2006/4 OECD's FDI regulatory restrictiveness index: Revision and extension to more economies

2006/3 Interpretation of the Umbrella Clause in Investment Agreements

2006/2 Investor-State Dispute Settlement in Infrastructure Projects

2006/1 Improving the System of Investor-State Dispute Settlement: An Overview

2005

2005/3 Corporate Responsibility Practices of Emerging Market Companies - A Fact-Finding Study

2005/2 Multilateral Influences on the OECD Guidelines for Multinational Enterprises

2005/1 Transparency and Third Party Participation in Investor-State Dispute Settlement Procedures 
2004/6 Mobilising Investment for Development: Role of ODA - The 1993-2003 Experience in Vietnam

2004/5 ODA and Investment for Development: What Guidance can be drawn from Investment Climate Scoreboards?

2004/4 Indirect Expropriation and the Right to Regulate in International Investment Law

2004/3 Fair and Equitable Treatment Standard in International Investment Law

2004/2 Most-Favoured-Nation Treatment in International Investment Law

2004/1 Relationships between International Investment Agreements

Business Approaches to Combating Corrupt Practices

$2003 / 1$

Incentives-based Competition for Foreign Direct Investment: The Case of Brazil

2002

2002/2 Managing Working Conditions in the Supply Chain: A Fact-Finding Study of Corporate Practices

2002/1 Multinational Enterprises in Situations of Violent Conflict and Widespread Human Rights Abuses

2001

2001/6 Codes of Corporate Conduct: Expanded review of their contents

2001/5 The OECD Guidelines for Multinational Enterprises and other corporate responsibility instruments

2001/4 Public policy and voluntary initiatives: What roles have governments played?

2001/3 Making codes of corporate conduct work: Management control systems and corporate responsibility

2001/2 Corporate Responsibility: Results of a fact-finding mission on private initiatives

2001/1 Private Initiatives for Corporate Responsibility: An Analysis

2000

2000/5 Recent trends, policies and challenges in South East European countries

2000/4 Main determinants and impacts of FDI on China's economy

2000/3 Lithuania: Foreign Direct Investment Impact and Policy Analysis

2000/2 Investment Patterns in a Longer-Term Perspective

2000/1 Bribery and the business sector: Managing the relationship

\section{9}

1999/3 Rules for the Global Economy: Synergies between Voluntary and Binding Approaches

1999/2 Deciphering Codes of Corporate Conduct: A Review of their Contents

1999/1 Southeast Asia: the Role of FDI Policies in Development

1998

1998/1 Survey of OECD work on international investment 